\title{
Upper Pleistocene and Holocene palaeoenvironmental records in Cueva Mayor karst (Atapuerca, Spain) from different proxies: speleothem crystal fabrics, palynology, and archaeology
}

\author{
Virginia Martínez-Pillado*1,2, Arantza Aranburu ${ }^{1,2}$, Juan Luis Arsuaga ${ }^{3,4}$, \\ Blanca Ruiz-Zapata ${ }^{5}$, Maria José Gil-García ${ }^{5}$, Heather Stoll ${ }^{6}$, Iñaki Yusta ${ }^{1}$, \\ Eneko Iriarte ${ }^{2,7}$, José Miguel Carretero ${ }^{7}$, R. Lawrence Edwards ${ }^{8}$, and Hai Cheng 8,9 \\ ${ }^{1}$ Department of Mineralogy and Petrology, Faculty of Science and Technology, Universidad del País Vasco (UPV/EHU), 48940 Leioa, Bizkaia \\ ${ }^{2}$ ARANZADI Geo-Q, b/ Kortasenebarri s/n, 48940 Leioa, Bizkaia, Spain \\ ${ }^{3}$ Department of Palaeontology, Faculty of Geological Science, Universidad Complutense de Madrid, Ciudad Universitaria, 28040 Madrid, Spain \\ ${ }^{4}$ UCM-ISCIII Mixed Centre of Human Development and Behaviour, C/ Monforte de Lemos, 5, 28029 Madrid, Spain \\ Department of Geology, Faculty of Science, Universidad de Alcalá, Campus Universitario, 28871 Alcalá de Henares, Madrid, Spain \\ ${ }^{6}$ Faculty of Geology, Campus de Llamaquique Jesús Arias de Velasco s/n, 33005 Oviedo, Spain \\ ${ }^{7}$ Laboratory of Human Evolution, Dept. of Historical Science and Geography, Universidad de Burgos, Edificio I+D+i, Plaza de Misael Buñuelos s/n, \\ 09001 Burgos, Spain \\ ${ }^{8}$ Department of Earth Sciences, University of Minnesota, Minneapolis, MN 55455, USA \\ Institute of Global Environmental Change, Xian Jiaotong University, Xian 710049, China
}

\begin{abstract}
The Cueva Mayor karst system of Atapuerca, in Northern Spain, hosts a highly significant record of human occupation from the Pleistocene. The climatic context of the human activities during the Pleistocene-Holocene for this inland site has not been well constrained, since existing records of the palaeoclimatic evolution of the Northern Iberian Peninsula are from more distal coastal and high-elevation sites. In this study, we interpret the palaeoenvironmental information recorded on the petrography of a stalagmite and the pollen spectra of the Sierra de Atapuerca karst system during the last 20 kyr. The integration of both types of records has allowed us to define four palaeoenvironmental stages. During the Upper Pleistocene and until $12.8 \mathrm{kyr} \mathrm{BP}$, the climate was cold and dry, toward the end of the interval evolving to wetter and warmer conditions. From 12.8 to $7.7 \mathrm{kyr} \mathrm{BP}$, during the Mesolithic-Neolithic, a major erosion event in both records marks the Pleistocene-Holocene transition. Around $5.9 \mathrm{kyr}$ BP, the Late Neolithic, environmental conditions indicate a climatic optimum with a marked seasonality. The environmental conditions became drier from $4.2 \mathrm{kyr}$ BP until the present, with a decrease in the woodlands. This aridity signal might be amplified by the impact of a more intense human agricultural activity after $3.1 \mathrm{kyr}$ BP, during the Bronze Age.
\end{abstract}

Keywords: $\quad$ palaeoenvironmental record; stalagmite; pollen; human impact; U/Th-radiocarbon dating Received 10 January 2013; Revised 5 June 2013; Accepted 15 October 2013

Citation: $\quad$ Martínez-Pillado V., Aranburu A., Arsuaga J.L., Ruiz-Zapata B., Gil-García M.J., Stoll H., Yusta I., Iriarte E., Carretero J.M., Edwards R.L. and Cheng H., 2014. Upper Pleistocene and Holocene palaeoenvironmental records in Cueva Mayor karst (Atapuerca, Spain) from different proxies: speleothem crystal fabrics, palynology and archaeology. International Journal of Speleology, 43 (1), 1-14. Tampa, FL (USA) ISSN 0392-6672 http://dx.doi.org/10.5038/1827-806X.43.1.1

\section{INTRODUCTION}

The Sierra de Atapuerca is located in the north centre of the Iberian Peninsula, in the transition between Mediterranean and Atlantic climate regions, $15 \mathrm{~km}$ to the east of the city of Burgos, between the Ebro and Duero basins (Fig. 1a). The low-altitude ridge $(1078 \mathrm{~m})$ in the Arlanzón River Valley contains a large number of karstic cavities formed in Cretaceous limestones. The karstic system has been filled by different types of sediment during the Pleistocene since at least 1.4 million year (Falguères et al., 2001; Carbonell et al., 2008; Moreno et al., 2012) and during the Holocene, up to 1000 yr BP (Carretero et al., 2008). The archaeological and palaeontological sites of Atapuerca contain some of the most exceptional accumulations of human fossils and stone artifacts from the Pleistocene (e.g. Carbonell et al., 1995; Arsuaga et al., 1997; Bermúdez de Castro et al., 1997; Martínez et al., 2004; Carbonell et al., 2008).

One of the largest cave complexes in the karst system is Cueva Mayor-Cueva del Silo, which extends 
for $4 \mathrm{~km}$ and contains 3 karstic floors formed in different chronological episodes. The upper level is the longest, over $10 \mathrm{~m}$ wide and $15 \mathrm{~m}$ high, and attains an elevation of $1036 \mathrm{~m}$ in the collapse sinkholes at the entrance (Ortega Martinez, 2009). This upper floor contains the two areas studied in this paper: Galeria de Estatuas and El Portalón (Fig. 1b).

The Galeria de Estatuas is a subhorizontal gallery with abundant formation of speleothems whose modern-recent deposition is predominantly as laminartype flowstones and diffuse drips leading to extensive development of stalactites and stalagmites that cover the ceiling and floor of the cave, fossilizing an archaeopalaeontological Pleistocene record. There is also evidence of Holocene human activity as shown by the presence of storage pits (Ortega Martínez, 2009).

The El Portalón site is a natural entrance to the upper level of the Cueva Mayor karst, making it one of the key points for the existence and location of an area of habitation inside Cueva Mayor. The archaeostratigraphic succession identified spans from the Upper Pleistocene (34.8 cal kyr BP) to the Middle Ages. The main units differentiated in the El Portalon site (Fig. 2) are from bottom to top (see Carretero et al., 2008 for detailed dating):

- Unit 10 (Late Pleistocene) - This is the deepest sedimentary unit and is nearly $4 \mathrm{~m}$ thick (minimum observed thickness). It is divided into
12 sub-levels from P1 to P12. It is characterized by an alternation of angular limestone clast debritic layers, sandy clay layers and clay layers. This unit contains abundant microfaunal and macrofaunal remains (López-García et al., 2010). Four small flint blades were recovered in the P8 sub-level.

- Unit 9a (Holocene-Pleistocene transition) Consists of a 5 to $8 \mathrm{~cm}$ thick layer of bat guano right below Unit 9. It represents the transition from the Pleistocene (Unit 10) to the Holocene (Unit 9) characterised by the absence of human occupations in the site. This guano layer denotes an interruption of the detritic sedimentation.

- Unit 9 (Neolithic and Mesolithic) - This is the bottom part of the Holocene sequence and is a homogenous blackish clayey layer with abundant organic matter and charcoal fragments. Subangular limestone clasts and blocks $(10-20 \mathrm{~cm})$ are together with some rounded quartzite gravels. It has an average thickness of $125 \mathrm{~cm}$ in the south profile. At the base of this thick layer a $75-80 \mathrm{~cm}$ depth pit is excavated in underlying units (9a and 10). Most of Unit 9 corresponds to the Neolithic with handmade potshards, macrofaunal remains, stone tools and bone tools. At the base of this unit, Mesolithic chronologies (8580 cal yr BP) were obtained from a charcoal

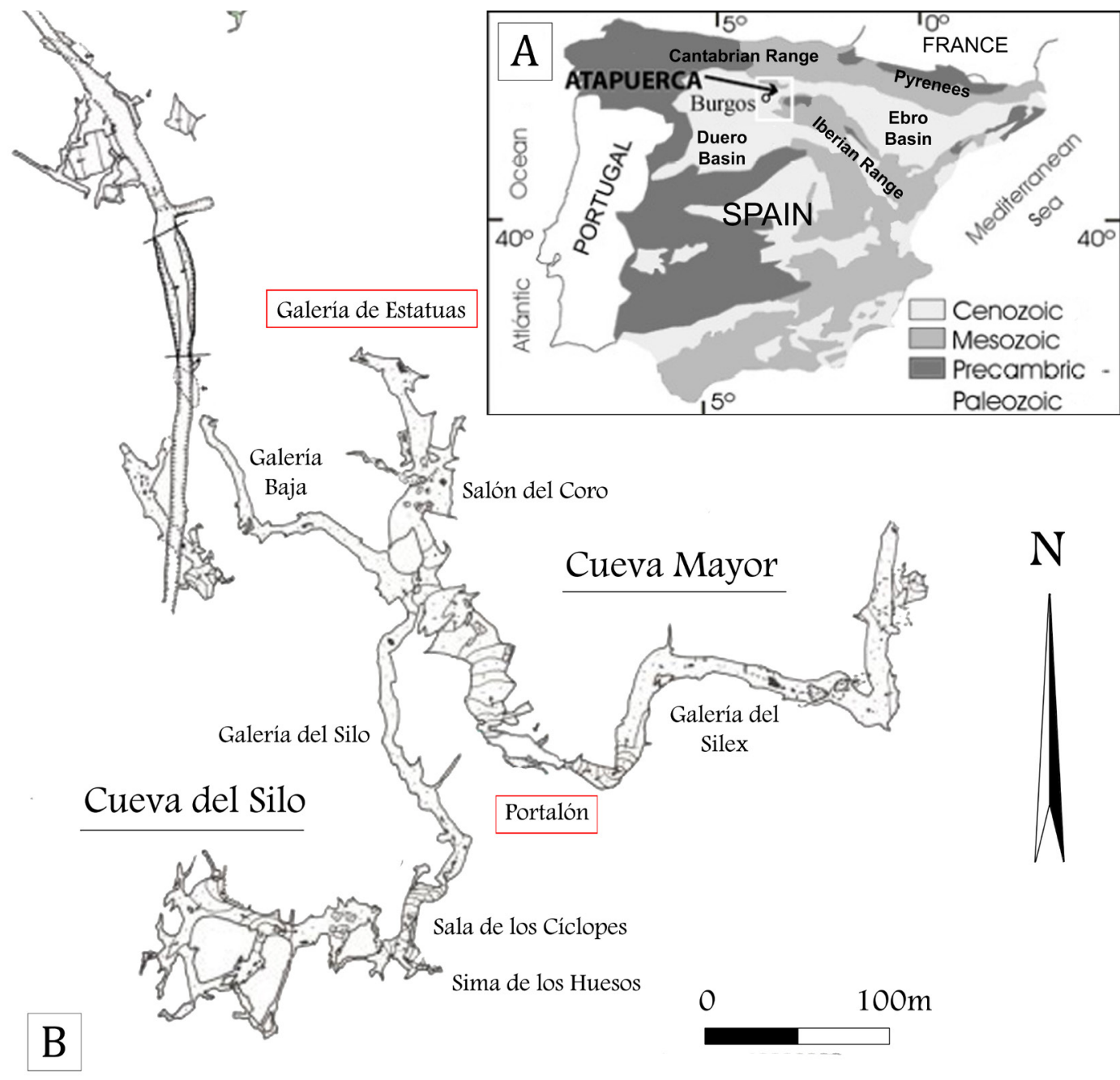

Fig. 1. A) Location of the Sierra de Atapuerca in the Iberian Peninsula (Modified from Ortega Martínez, 2009); B) Location of Galería de Estatuas and El Portalón site at Cueva Mayor karst (Modified from G.E. Edelweiss). 


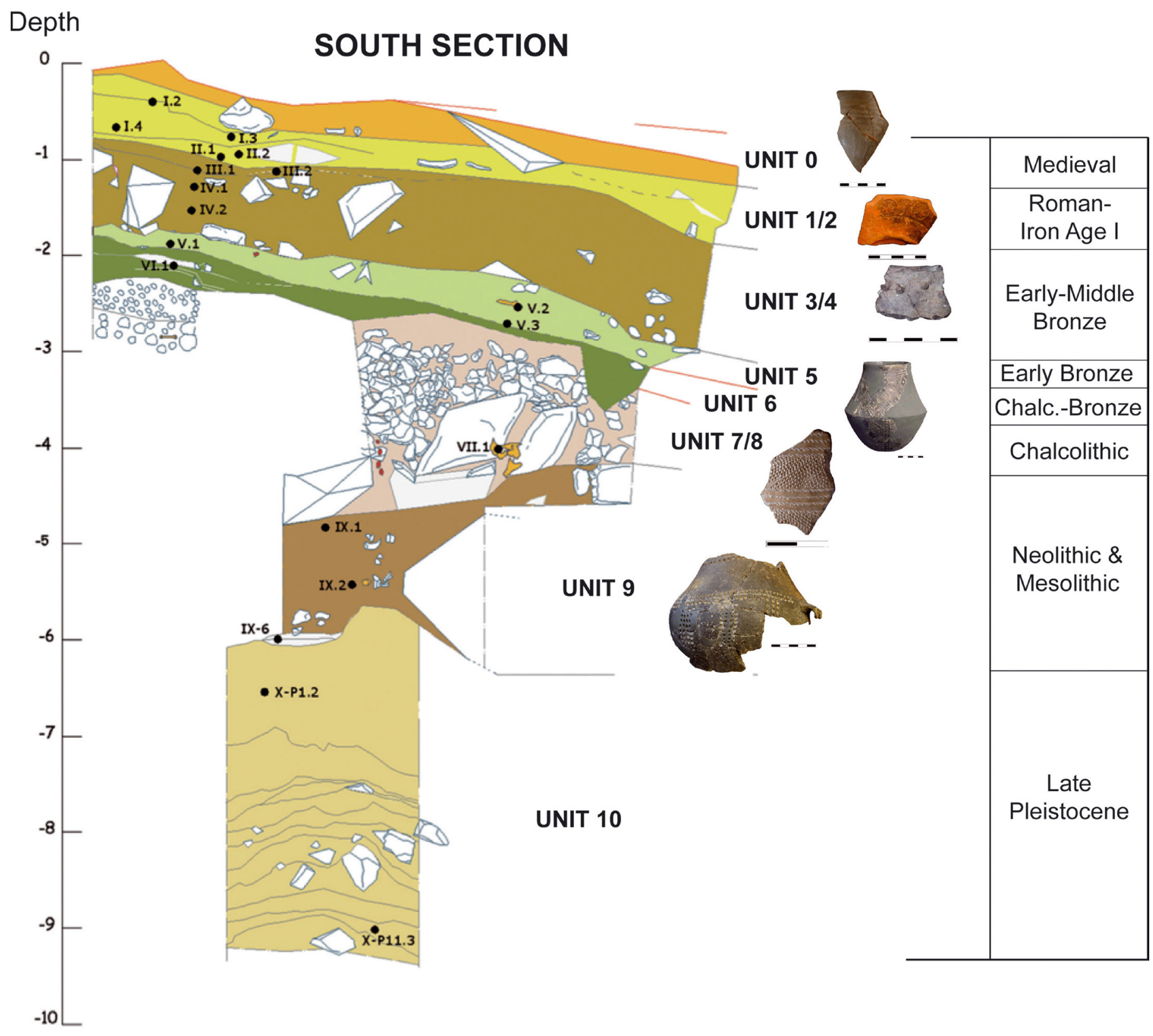

Fig. 2. Stratigraphic sketch of the South profile of El Portalón archaeological site. Black dots indicate the position of the samples for radiocarbon dating.

fragment (Carretero et al., 2008). This unit indicates a large occupation during the Neolithic and perhaps during the Mesolithic.

- Unit $7 / 8$ (Chalcolithic) - These units are composed of angular to subangular limestone clasts (15-20 $\mathrm{cm})$ that increase in size downwards. The base of this unit consists of large limestone blocks from a roof collapse. Abundant human bones, pottery and animal remains are present in this unit. A large ceramic vessel with decorations of pellets, a copper awl and the presence of two goat skeletons on the two large flat stones at the base, suggest the occurrence of burial activities in the site during the Chalcolithic. It has a maximum thickness of $200 \mathrm{~cm}$.

- Unit 6 (Bronze Age-Chalcolithic transition) Consists of $30-35 \mathrm{~cm}$ of grey silty-clay with abundant organic matter and charcoal. It encloses many ash lenses in its lower half. Potshards and animal bones are present.
- Unit 5 (Early Bronze Age) - Consists of greyish sandy-clay with an average thickness of about $35 \mathrm{~cm}$. Its lower part is rich in charcoal and ash layers. There are abundant potshards and domestic animal bones.

- Unit 4 (Early Bronze Age) - Consist of a homogeneous layer of dark grey sandy-clay. It is 70 to $150 \mathrm{~cm}$ thick. This unit contains abundant organic matter and charcoal remains, with numerous large limestone blocks resulting from a collapse of the cave roof. Abundant hand-made potshards, stone tools and animal bones are found in this unit.

- Unit 3 (Middle Bronze Age) - Consists of a thin set of dark sandy-clay layers of about $16 \mathrm{~cm}$ in thickness. Organic material is abundant with abundant charcoal, hand-made pottery fragments and bones of domestic and wild animals (Clark et al., 1979).

- Unit 2 (Iron Age I) - Consists of dark clay organic sediment of anthropogenic origin with abundant 
ash. Its maximum thickness is $30 \mathrm{~cm}$. Hand-made pottery was recovered in this unit (Clark et al., 1979).

- Unit 1 (Roman) - Dark grey clays with charcoal fragments and intercalations of ashy layers. It contains small limestone clasts and its maximum thickness is $40 \mathrm{~cm}$. Archaeological artifacts include abundant potshards, including Roman terra sigillata.

- Unit 0 (Medieval) - Corresponds to the first 15 to $68 \mathrm{~cm}$ of the top of the sequence and is composed of brown silty deposits with charcoal, bone and pottery fragments.

Paleoclimatic data for the Upper Palaeolithic, Mesolithic and Neolithic cultural periods in the hinterland of the Iberian Peninsula are scarce. The available palaeoenvironmental data include the isotopic record of some speleothems (Muñoz et al., 2001; Muñoz-García, 2007; Dominguez-Villar, 2008; Moreno et al., 2010; Martin-Chivelet et al., 2011) and the pollen record of wetlands and archeological sites (Peñalba et al., 1997; Gil García et al., 2001, 2002; Ruiz Zapata et al., 2002, 2003a, 2003b, 2003c; Vegas et al., 2003; Carrión, 2012). However, no work has been done to compile and compare the different records.

The aim of this study is to correlate the environmental signals from different proxies recorded in the Cueva Mayor karst: the petrological record of a stalagmite (Ilargi) from Galeria de Estatuas and the archaeological and palynological record of the detrital sequence of El Portalón site, taking the time interval in which their chronologies overlap.

\section{MATERIAL AND METHODS}

In the Galeria de Estatuas, the study focused on a stalagmite corresponding to the final phase of speleothem precipitation. The speleothem development is related to the microporosity of the host rock (dolomitized limestones) without significant fissures from which the dripping water might preferentially flow. The floor of the cave is covered with stalagmites of similar diameter $(7-9 \mathrm{~cm})$ and height $(25-30 \mathrm{~cm})$ that grow upon the detritic endokarstic sediments. One of these stalagmites (named Ilargi) was sampled to study its petrological features and evolution. Ten thin sections covering the entire stratigraphy of the stalagmite were studied using the terminology proposed by Kendall \& Broughton (1978), Frisia et al. (2000, 2002) and Frisia $\&$ Borsato (2010). The crystal fabrics of the speleothem make it possible to reveal differences in the growth rate, the dripping rate and the degree of carbonate saturation during stalagmite formation. It was also fundamental to discriminate diagenetic features, allowing a correct interpretation of the chronological data, growth rate and paleo-dripping information. The thin-sections were obtained after cutting the stalagmite with a diamond saw and were studied using an OLYMPUS BH2 petrographic microscope equipped with an Olympus DP10 digital photo system.

Several instrumental techniques were used to characterize the mineralogy and geochemistry of the different fabrics observed in the stalagmite. Mineralogical characterization of the speleothem was obtained by powder X-ray diffraction (PXRD) with a PANalytical X’Pert Pro diffractrometer (X'Pert software with ICDD database) at the SGIker researcher facilities of the UPV/EHU. Micro-drilled samples from the stalagmite were finely ground in an agate mortar, mounted in silicon zero-background plates, and processed using a continuous scan range of $2-80^{\circ}$ $2 \theta$ with $\mathrm{Cu} \mathrm{Ka}$ radiation, $40 \mathrm{kV}, 40 \mathrm{~mA}$, graphite monochromator and an automatic slit. Scanning electron microscopy (SEM) equipped with energy dispersive X-ray analysis (EDS) was used to determine the microtextural characteristics and semi-quantitative composition of the fabrics defined by light microscopy. Small chips from the key textural zones were attached onto the surface of SEM brass stubs, graphite-coated and examined using a JEOL JSM-7000F microscope. For samples where a very intimate growth between carbonate and detrital material occurs, a first step of dissolution in $1 \mathrm{M} \mathrm{HCl}$ was performed to isolate the noncarbonate fraction of the speleothem. The solutions obtained were thoroughly washed with Milli-Q water to avoid calcium chloride precipitation, and then two drops were poured over double-sided adhesive carbon tape onto SEM carbon stubs.

Eight samples of 80 to $270 \mathrm{mg}$ were drilled along the longitudinal axis of Ilargi and prepared for U-Th dating following the methodology described in Moreno et al. (2010). Dates from U-Th decomposition were obtained at the University of Minnesota using the methodology described in Cheng et al. (2009) and Shen et al. (2002) and measured with ICP-MS (ThermoFinnigan ELEMENT) or MC-ICP-MS (Thermo-Finnigan Neptune). Details of the obtained dates, U contents, and corrected initial $\delta{ }^{234} \mathrm{U}$ ratios are given in Table 1 .

In addition, a ${ }^{14} \mathrm{C}$ (AMS) age was obtained from a charcoal fragment found inside the speleothem. The analysis (Table 2) was performed in the Radiocarbon Accelerator Unit of the University of Oxford (UK).

In the El Portalón archaeological site, the pollen study was carried out on the sequence located in the south profile of the excavation area. It is very well dated, based on $27{ }^{14} \mathrm{C}$ (AMS) dating of charcoal and bone fragments (Carretero et al., 2008). Pollen samples were taken on the previously cleaned profile, using standardised techniques for archaeological sites (López Sáez et al., 2003). The pollen was extracted by chemical treatment with acids ( $\mathrm{HCl}$ and $\mathrm{HF}$ ) and alkalis $(\mathrm{KOH})$, based on the standard protocol proposed by Coûteaux (1977), Girard \& Renault-Miskovsky (1969) and Moore et al., (1991), modified according to the specific requirements of the lithology of each sample. The residue obtained was then subjected to enrichment techniques, concentrating the pollen grains by flotation in Thoulet dense liquor (Goeury \& Beaulieu, 1979). The data obtained were statistically analysed and plotted using the TILIA ${ }^{\circledR}$ and TILIA-GRAPH ${ }^{\circledR}$ software packages (Grimm, 1987). The relative values of the tree, shrub and grass taxa were obtained from the total absolute values of each one. They refer to the total pollen base, which does not include hydro-hygrophytic taxa and non-pollen microfossils (NPMs), whose local nature means that they might be over-represented. The relative percentage of these palynomorphs in the total pollen 
Table 1. U-Th dating of the Ilargi stalagmite.

\begin{tabular}{|c|c|c|c|c|c|c|c|c|c|c|c|c|c|c|c|c|c|c|}
\hline \multirow{2}{*}{\multicolumn{2}{|c|}{$\begin{array}{l}\text { Sample ID } \\
\text { Deep }(\mathrm{Cm})\end{array}$}} & \multirow{3}{*}{$\begin{array}{c}\text { Weight } \\
\mathrm{g} \\
0.2529\end{array}$} & \multirow{2}{*}{\multicolumn{2}{|c|}{$\begin{array}{l}{ }^{238} \mathrm{U} \\
\mathrm{ppb}\end{array}$}} & \multirow{2}{*}{\multicolumn{2}{|c|}{$\begin{array}{l}{ }^{232} \mathrm{Th} \\
\mathrm{ppt}\end{array}$}} & \multirow{2}{*}{\multicolumn{2}{|c|}{$\frac{\delta^{234} \mathrm{U}}{\text { measured }^{\mathrm{a}}}$}} & \multirow{2}{*}{\multicolumn{2}{|c|}{$\frac{\left[{ }^{230} \mathrm{Th} /{ }^{238} \mathrm{U}\right]}{\text { activity }^{\mathrm{c}}}$}} & \multirow{2}{*}{\multicolumn{2}{|c|}{$\begin{array}{c}\left.{ }^{[230} \mathrm{Th} /{ }^{232} \mathrm{Th}\right] \\
\mathrm{ppm}^{\mathrm{d}}\end{array}$}} & \multirow{2}{*}{\multicolumn{2}{|c|}{$\begin{array}{c}\text { Age } \\
\text { uncorrected }\end{array}$}} & \multirow{2}{*}{\multicolumn{2}{|c|}{$\begin{array}{c}\text { Age } \\
\text { corrected c,e }\end{array}$}} & \multirow{2}{*}{\multicolumn{2}{|c|}{$\begin{array}{c}\delta^{234} U_{\text {initial }} \\
\text { corrected }\end{array}$}} \\
\hline & & & & & & & & & & & & & & & & & & \\
\hline - & 2.5 & & 61 & \pm 0 & 761 & \pm 4 & -23.2 & \pm 8.0 & 0.03953 & \pm 0.00167 & 52.1 & \pm 2.2 & $4,506.40$ & \pm 198.0 & 4,133 & \pm 271 & -23.5 & \pm 8.1 \\
\hline a & 3.5 & 0.16 & 147 & \pm 1 & 924 & \pm 6 & -14.7 & \pm 3.7 & 0.02944 & \pm 0.00086 & 77.5 & \pm 2.3 & $3,307.50$ & \pm 98.4 & 3,122 & \pm 135 & -14.8 & \pm 3.7 \\
\hline b & 4 & 0.1727 & 62 & \pm 0 & 535 & \pm 5 & -21.3 & \pm 6.1 & 0.03907 & \pm 0.00154 & 74.9 & \pm 3.0 & $4,443.00$ & \pm 180.8 & 4,187 & \pm 221 & -21.5 & \pm 6.2 \\
\hline - & 6 & 0.1994 & 52 & \pm 0 & 2397 & \pm 11 & -29 & \pm 5.6 & 0.09013 & \pm 0.00258 & 32.2 & \pm 0.9 & $10,628.30$ & \pm 326.1 & 9,233 & \pm 771 & -29.8 & \pm 5.7 \\
\hline c & 7.5 & 0.237 & 51 & \pm 0 & 1675 & \pm 7 & -14.2 & \pm 8.2 & 0.05525 & \pm 0.00180 & 27.5 & \pm 0.9 & $6,289.90$ & \pm 218.4 & 5,309 & \pm 537 & -14.4 & \pm 8.3 \\
\hline$d$ & 13 & 0.214 & 66 & \pm 0 & 880 & \pm 5 & -29 & \pm 5.2 & 0.05478 & \pm 0.00146 & 68.2 & \pm 1.8 & $6,333.90$ & \pm 177.8 & 5,936 & \pm 266 & -29.5 & \pm 5.3 \\
\hline e & 15 & 0.3254 & 61 & \pm 0 & 1170 & \pm 5 & 3.6 & \pm 3.5 & 0.11599 & \pm 0.00162 & 100.2 & \pm 1.4 & $13,391.60$ & \pm 205.2 & 12,837 & \pm 344 & 3.7 & \pm 3.7 \\
\hline$f$ & 22 & 0.434 & 66 & \pm 0 & 1105 & \pm 4 & 12 & \pm 9.2 & 0.12337 & \pm 0.00222 & 121.2 & \pm 2.1 & $14,173.00$ & \pm 305.7 & 13,689 & \pm 387 & 12.5 & \pm 9.5 \\
\hline
\end{tabular}

Analytical errors are $2 \sigma$ of the mean.

a $\delta^{234} U=\left([234 \mathrm{U} / 238 U]_{\text {activity }}-1\right) \times 1000$.

${ }^{b} \delta^{234} U_{\text {initial }}$ corrected was calculated based on ${ }^{230} T h$ age $(T)$, i.e., $\delta^{234} U_{\text {initial }}=\delta^{234} U_{\text {measured }} X e^{\delta^{2344} \mathrm{~T}}$, and $\mathrm{T}$ is corrected age.

c $\left[{ }^{230} \mathrm{Th} /{ }^{238} \mathrm{U}\right]_{\text {activity }}=1-\mathrm{e}^{-\delta^{23 x_{*}} \mathrm{~T}}+\left(\delta^{234} \mathrm{U}_{\text {measured }} / 1000\right)\left[\delta^{230} /\left(\delta^{230}-\delta^{234}\right)\right]\left(1-\mathrm{e}^{-\left(\delta^{-230}-\delta^{234}\right)} \mathrm{T}\right)$, where $T$ is the age.

Decay constants are $9.1705 \times 10^{-6} \mathrm{yr}^{-1}$ for ${ }^{230} \mathrm{Th}, 2.8221 \times 10^{-6} \mathrm{yr}^{-1}$ for ${ }^{234} \mathrm{U}$, and $1.55125 \times 10^{-10} \mathrm{yr}^{-1}$ for ${ }^{238} \mathrm{U}$.

${ }^{\mathrm{d}}$ The degree of detrital ${ }^{230} \mathrm{Th}$ contamination is indicated by the $\left[{ }^{230} \mathrm{Th} / 232 \mathrm{Th}\right]$ atomic ratio instead of the activity ratio.

${ }^{e}$ Age corrections were calculated using an average crustal ${ }^{230} \mathrm{Th} /{ }^{232} \mathrm{Th}$ atomic ratio of $4.4 \times 10^{-6} \pm 2.2 \times 10^{-6}$.

Those are the values for a material at secular equilibrium, with the crustal ${ }^{232} \mathrm{Th} / 238 \mathrm{U}$ value of 3.8 . The errors are arbitrarily assumed to be $50 \%$.

Table 2. Radiocarbon dating of a charcoal fragment from the Ilargi stalagmite. Calibrated age was calculated using IntCal09 Curve.

\begin{tabular}{|c|c|c|c|c|c|}
\hline OxA & Sample & Material (species) & $\delta^{13} \mathrm{C}$ & Conventional radiocarbon age & Calibrated BP age $(2 \sigma)$ \\
\hline \multicolumn{6}{|c|}{ Atapuerca - Estatuas, Spain } \\
\hline OxA-25074 & ATA-ILARGI-2 & charcoal & -23.26 & $6927 \pm 37$ & $7759 \pm 81$ \\
\hline
\end{tabular}

was calculated. The pollen was zoned using a divisive classification with the CONISS software (Grimm, 1987), included in the TILIA ${ }^{\circ}$ package. To make it easier to read the pollen data, a synthetic pollen diagram was created by grouping the most relevant taxa according to their ecological affinities. A rarefaction analysis was performed to determine biological diversity, (Birks \& Line, 1992; Foote, 1992; Heck et al., 1975; Odgaard, 1999), using the ANALYTIC RAREFACTION 1.3 program (Bronk Ramsey et al., 2002).

\section{RESULTS}

\section{Stalagmite dating and growth rates \\ U-Th dating}

Eight samples from the Ilargi stalagmite were dated. Two of the dates were excluded from the age model as outliers by the StalAge algorithm (Scholz \& Hoffmann, 2011). These two anomalous points may result from open system behaviour, as the petrographic analysis suggests diagenesis in these portions of the stalagmite.

The six retained dates (" $a$ " to " $f$ ", Fig. 3) span over much of the Holocene and the Upper Pleistocene (Table I). The transition between the two periods is indicated by an erosive surface marking a sedimentary unconformity and a temporal hiatus.

\section{Radiocarbon dating}

A two-centimeter sized charcoal fragment, found inside the Ilargi stalagmite some millimetres atop a guano level (Fig. 4), was dated revealing an age of 7759 cal yr BP (Table 2). This date fits the dates obtained from U-Th series (asterisk in Fig. 3).

\section{Growth rates}

The speleothem growth rate during the Upper Pleistocene (13.7 - $12.8 \mathrm{kyr} \mathrm{BP})$ is quite fast, around $62 \mu \mathrm{m} / \mathrm{yr}$, and seems to be constant.
During the Holocene, the growth rate shows significant variations. Between 7.7 and $5.9 \mathrm{kyr}$ BP the average growth rate is $6.6 \mu \mathrm{m} / \mathrm{yr}$. Between 5.9 and 5.3 kyr BP, the faster growth rate is registered with $80 \mu \mathrm{m} /$ $\mathrm{yr}$, and decreases to $30 \mu \mathrm{m} / \mathrm{yr}$ from 5.3 and $4.2 \mathrm{kyr}$ BP. The lower growth rate was registered between 4.2 and $3.1 \mathrm{kyr} \mathrm{BP}$, with only $5 \mathrm{~mm}$ of calcite precipitation in 1000 years, $4.7 \mu \mathrm{m} / \mathrm{yr}$. During the last 3000 years the growth rate increased to $12 \mu \mathrm{m} / \mathrm{yr}$.

\section{Stalagmite growth and crystal fabrics}

Throughout the Ilargi stalagmite, significant differences in the crystal fabrics of growth laminae were observed. These features make it possible to differentiate four growth-stages, based on the mineralogy, type of crystalline texture and distinct surfaces.

A basal interval (Unit I) is characterised by the presence of a columnar calcite fabric (Fig. 5a) which consists of ordered stacking of crystals with a length-to-width ratio lower than 6:1, straight boundaries, arranged perpendicular to the substrate and elongated along the c axis. Competitive growth phenomena are absent. The size of the crystallites (Kendall \& Broughton, 1978) is between 0.3-0.5 mm wide and 1-3 mm long and they display a rhombohedral habit with flat faces. Some spans are formed by a modified open dendritic fabric (Fig. $5 b$ ) with crystals about $0.02-$ $0.05 \mathrm{~mm}$ wide and 2-4 $\mathrm{mm}$ long, which in many cases turn into columnar-microcrystalline texture with widths of around 1-3 $\mathrm{mm}$ and lengths of around 15-22 $\mathrm{mm}$.

In the upper end of the Unit I, an erosional surface can be observed which significantly erodes the previous calcite laminae (Fig. 5c) and creates an intercrystalline porosity that is filled by a caramel-coloured mineral precipitate of hydroxyapatite (Fig. 5d), resulting from guano deposits covering the unconformity. On top of this phosphatic layer appears a 0.5-2 mm micritic layer that encloses tiny quartz grains and phyllosilicates under $2 \mu \mathrm{m}$ in size (Fig. 5d). 


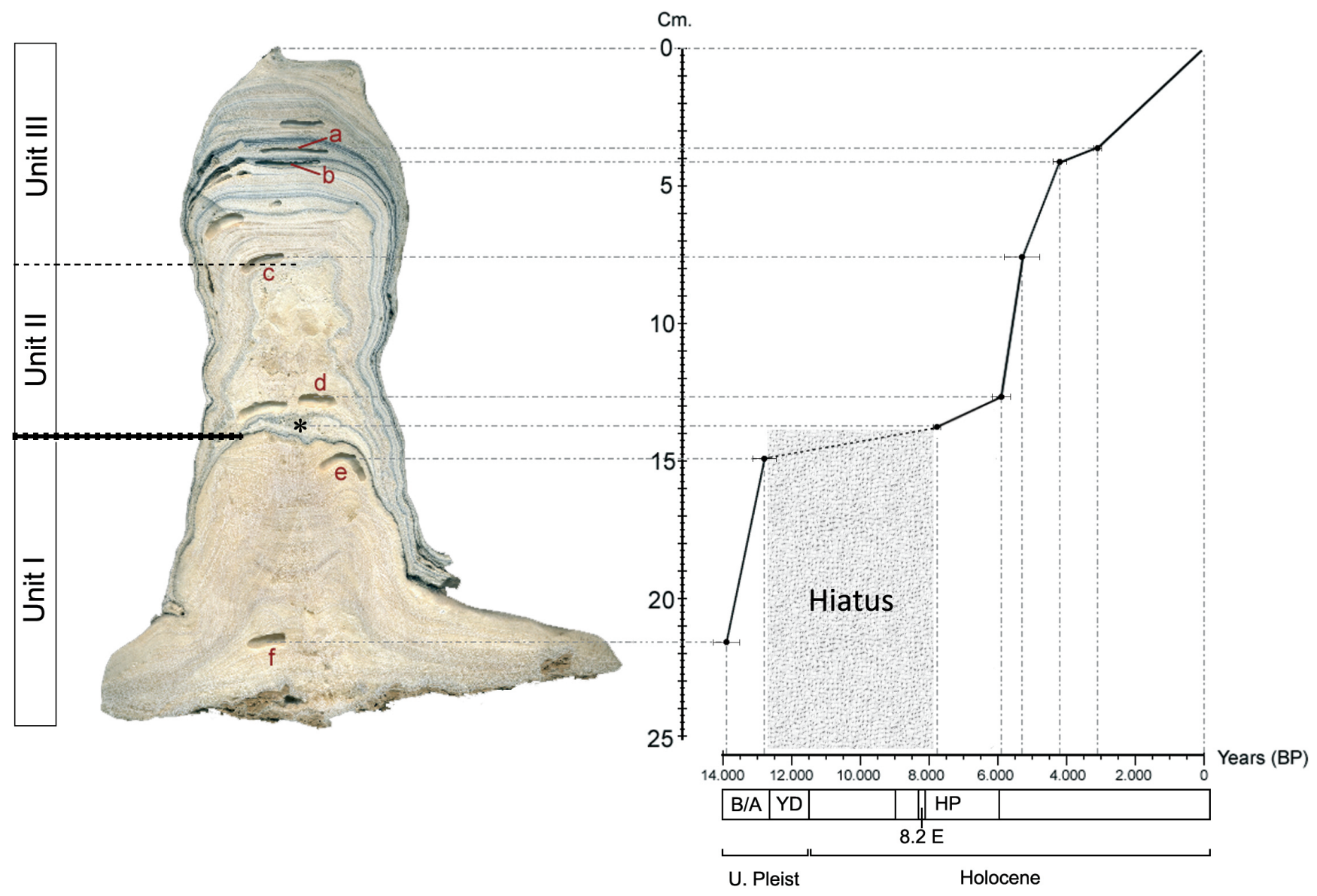

Fig. 3. Different stratigraphical units in the Ilargi stalagmite and its growth rate. Letters "a" to " $\mathrm{f}$ " indicate the position of the U/Th dating samples, and asterisk $\left(^{*}\right)$ indicates the stratigraphic position of the dated carbon sample.

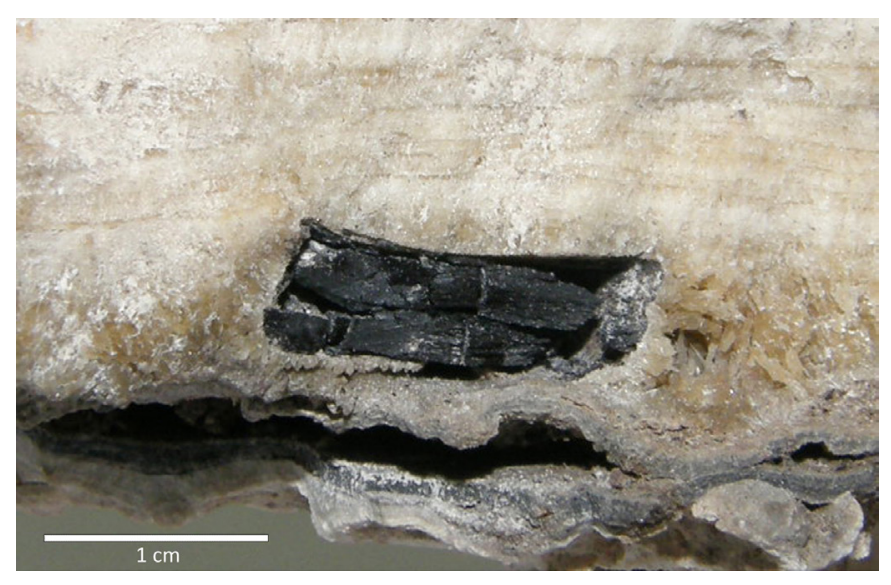

Fig. 4. Dated charcoal fragment found inside the Ilargi stalagmite.

Above the erosive surface, Unit II is characterised by whisker crystals at its base, $0.5 \mathrm{~mm}$ wide and 1 $\mathrm{mm}$ long (Fig. 5e). The unit follows with open dendritic crystals, sometimes embedded in a recrystallized texture of mosaic crystals. The dendritic fabric consists of branching polycrystals with high intercrystalline porosity (Fig. 5e). Competitive growth phenomena over the basal erosional surface are present. The habit of the dendritic crystals is well-developed rhombohedral with flat faces, 0.01-0.02 $\mathrm{mm}$ wide and 2.5-3 $\mathrm{mm}$ long, and some of them present a recrystallization phase forming large equidimensional crystals. The mosaic fabric is composed of euhedral rhombohedric crystals, with uniform patchy extinction. The size of these crystals ranges from $\mathrm{mm}$ to a few $\mathrm{cm}$. All replacement calcite crystals contain ghosts of the original aragonite texture (Fig. 5f). At the base of the Unit II, some charcoal fragments have been found atop the erosive unconformity (Fig. 4).

Finally, the upper interval (Unit III) shows an alternation of white and dark-brown laminae. The white laminae are typically 0.2 to $0.7 \mathrm{~cm}$ thick and are composed of microcrystalline calcite (Fig. $5 \mathrm{~g}$ ). Calcite laminae alternate with darker micritic and/or ash-rich laminae (Fig. 5h), composed of aggregates of soot, which sometimes have associated microscopic precipitates of hydroxyapatite. The crystal habits that form both white and dark laminae are about $10 \mu \mathrm{m}$ wide and $0.3 \mathrm{~mm}$ long. Several crystallites grow in optical continuity with the substrate, thereby forming domains with uniform to patchy extinction and interfingered boundaries, roughly oriented perpendicular to the growth surface, 1-2 $\mathrm{mm}$ wide and $17 \mathrm{~mm}$ long (Fig. $5 \mathrm{~g}$ ).

The differences observed in crystal fabrics (according to Frisia et al., 2000; 2002) have been related to changes in the environmental conditions of formation (drip rate, humidity, carbonate saturation, etc.). Unit I, characterized by the presence of the columnar fabric with some stretches of dendritic fabric, reflects stable drip rates and low calcite saturation of dripping water, typical of relatively wet conditions. The erosive surface shows a dissolutional hiatus (Fig. 5d), with truncation of underlying laminae, similar to the E-surface of Railsback et al. (2011). Above the unconformity, the presence of hydroxyapatite precipitate related to guano also indicates a change in the environmental conditions of the gallery. The presence of quartz and clastic grains is related to the rapid passage of 


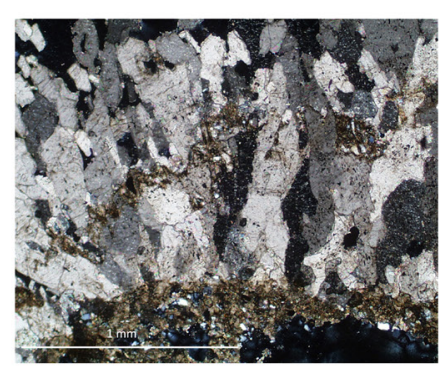

5 a
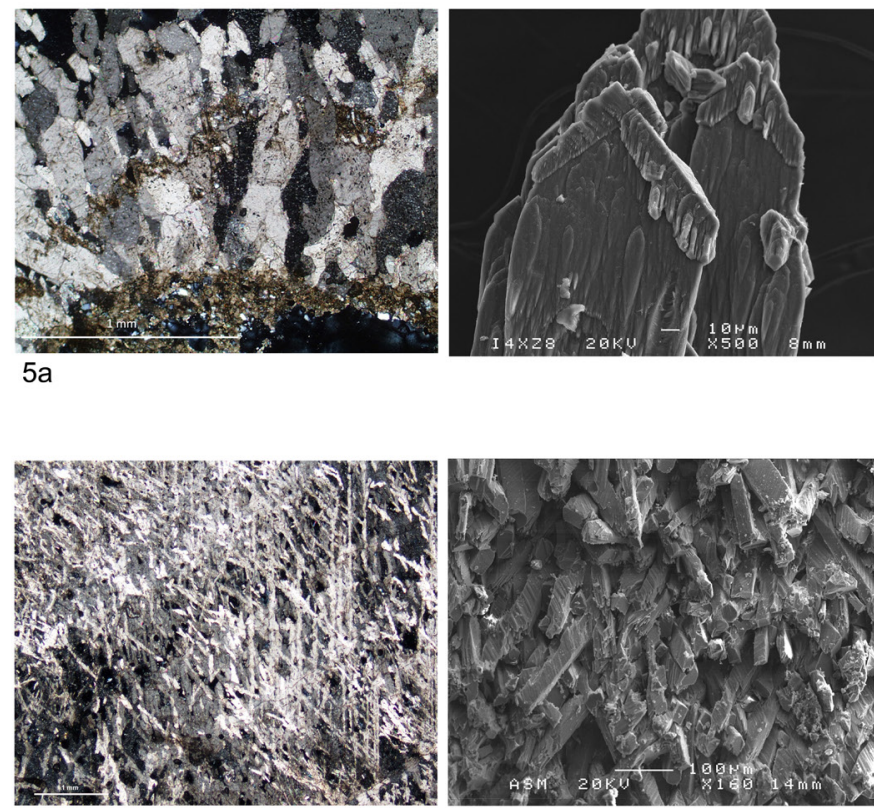

$5 b$

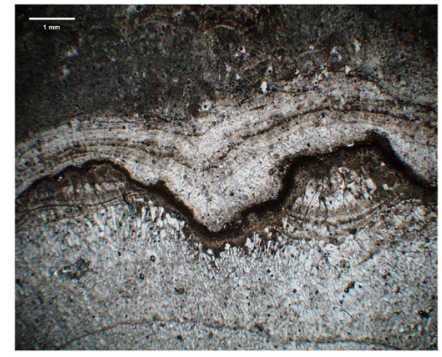

$5 c$
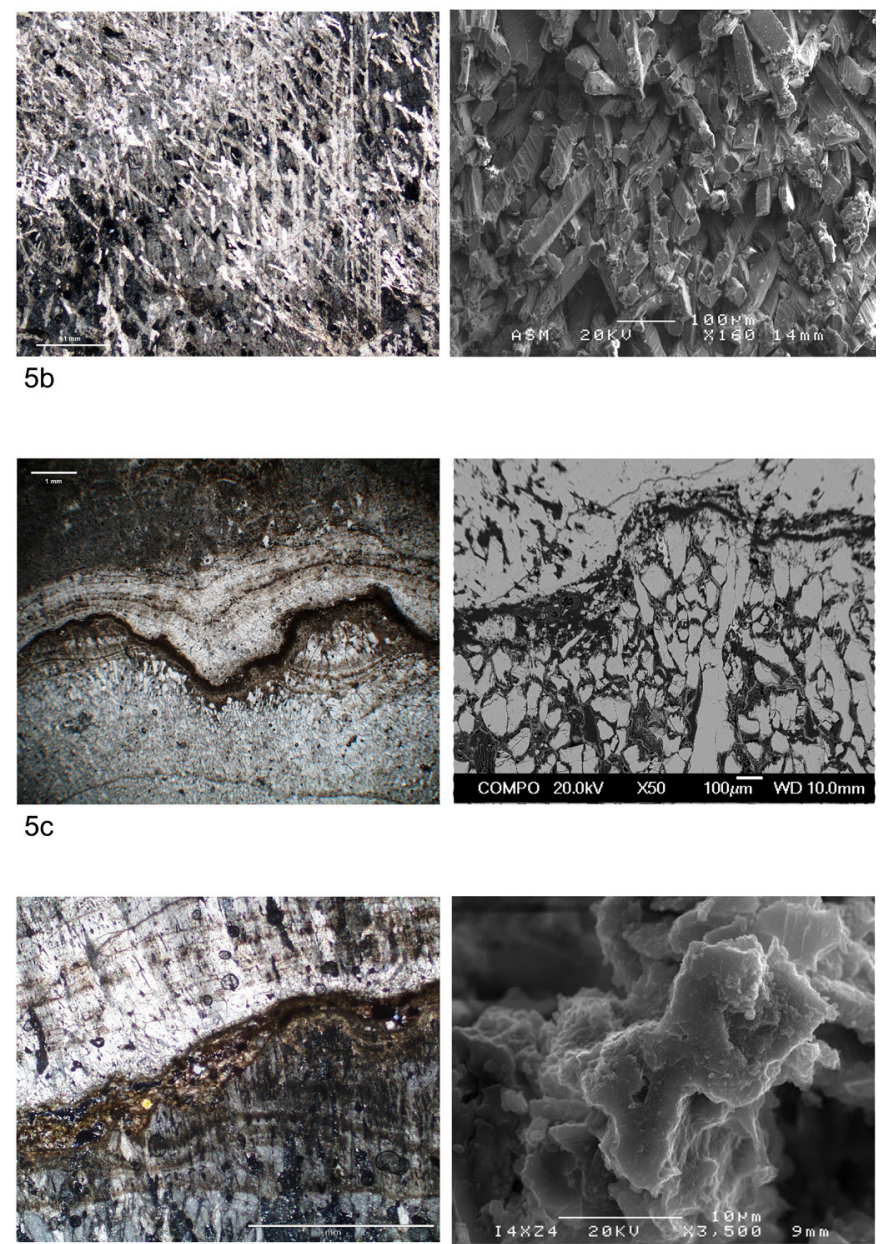

$5 d$

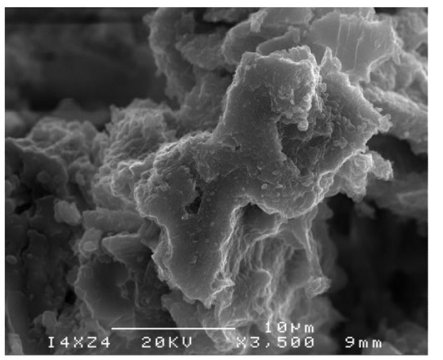

Fig. 5. Stalagmite growth and crystal fabrics under petrographic microscope (left) and SEM (right). a) Columnar fabric of sparitic calcite crystals. b) Dendritic fabric of aragonite crystals. c) Erosional surface. The dark level corresponds to the guano phase covered by the micritic layer. d) Detail of the erosional surface. Left: Micritic layer with quartz and phyllosilicates. Right: Local deposit of hydroxyapatite (HAp) over calcite crystals. e) Base of the Unit II with whisker fabric and open dendritic fabric atop. f) Recrystallization of calcite crystals showing ghosts of the original dendritic texture. g) Alternation of white and dark laminae composed of microcrystalline calcite fabric. $h$ ) Left: Detail of two ash-rich laminae. Right: Aggregates of soot carbon.

water through the soil, absence of vegetation and enhanced flow sufficient to carry detrital particles to the stalagmite (Railsback et al., 2011). This hiatus between $\sim 12$ and $\sim 8$ kyr BP may indicate a period of wetter climate with enhanced sub-saturated flow over the stalagmite causing dissolution on the previously precipitated carbonate, alternating with dry periods. Growth of Ilargi s recommenced around $8000 \mathrm{cal}$ yr BP with Unit II, which is characterized by an open dendritic fabric, suggesting variable (generally low) dripping rates, prolonged degasification periods and fluctuating calcite saturation conditions. This fabric reflects lower water availability than in Unit I, indicating drier conditions. Unit III is composed by microcrystaline fabric, indicating variable driprate and supersaturation index (in general relatively
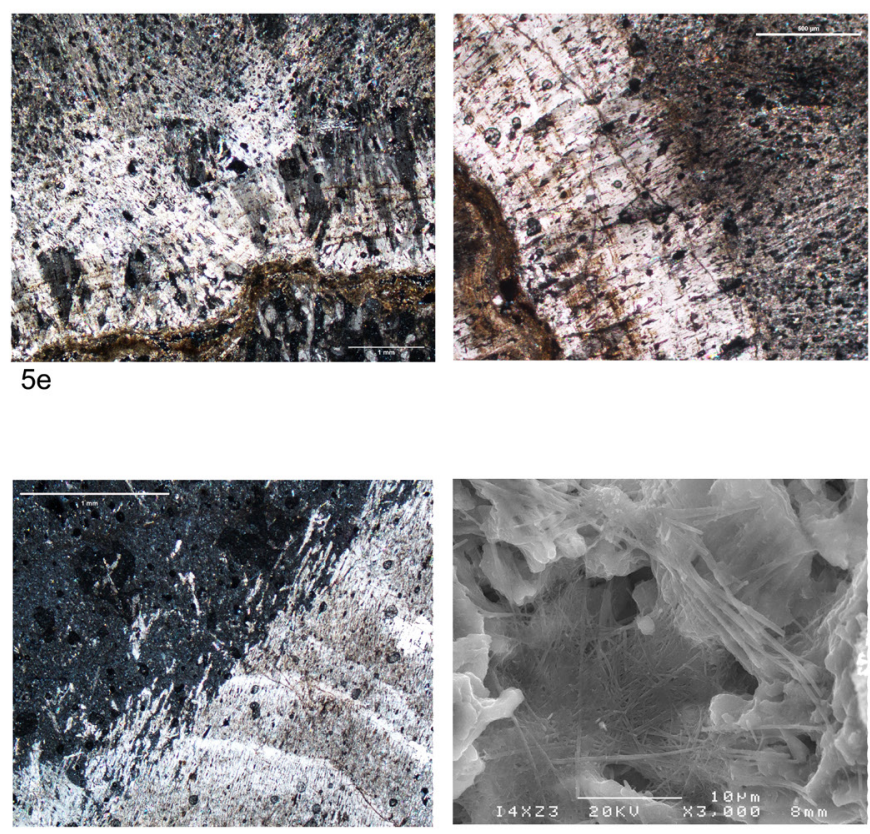

$5 f$
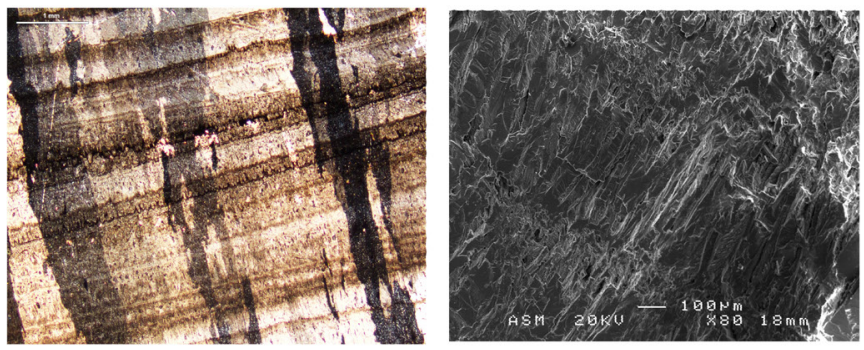

$5 \mathrm{~g}$

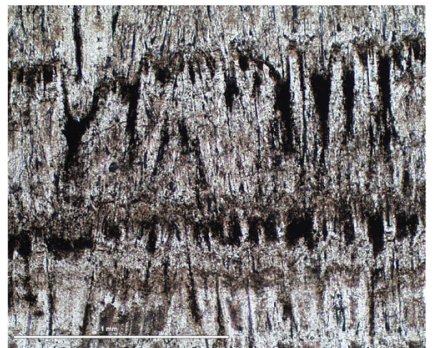

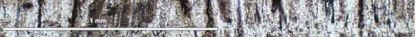

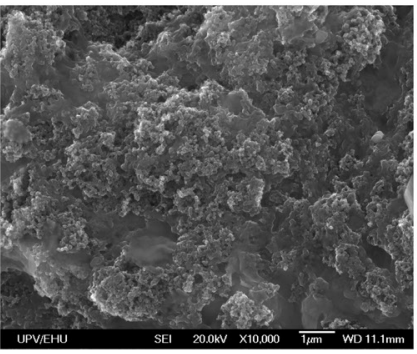

low). So, drier conditions are suggested during the formation of the youngest unit of Ilargi.

It must be stressed that fabric variations between different units generally occur abruptly and sometimes coincide with important erosion events or/and hiatuses.

\section{Pollen spectra}

The pollen record from the archaeo-stratigraphical sequence of the El Portalón site shows a strong contrast in the taxa between relatively open landscapes in the Late Pleistocene and greater development of woodlands throughout the Holocene (Fig. 6 and 7).

In the last samples from Pleistocene Unit 10, Pinus is the predominant tree at a regional level; at a local scale the most representative taxon is Corylus accompanied by deciduous Quercus and evergreen Quercus. The 
alternation observed between mesophilous, riparian and aquatic taxa -associated with a greater humidityand Asteraceae liguliflorae-tubuliflorae, Poaceae, Chenopodiaceae, Artemisia, and Ephedra, which are more xeric, indicate fluctuations of humidity throughout the sequence. Bushes and shrubs, which are sparsely represented, essentially consist of Ericaceae, although more occasionally Rosaceae, Calluna and Cistaceae have also been identified.

Above the erosive surface capped by the guano of Unit 9a, indicative of an interruption in the detritic sedimentation, the first Holocene sediments (Unit 9), show a progressive recovery of the tree group, with Pinus, as well as Corylus and riparian taxa, and finally by an increase in Mediterranean taxa. A major decline in xeric and steppe taxa can be observed. Nitrophilous taxa, represented essentially by Plantago, appear throughout the profile, associated with stages of greatest humidity and warmth.

The angular blocks and clasts of limestone, without detritic matrix and an outstanding absence of pollen record, constituted Unit $7 / 8$. After that, an increase in Pinus, Corylus, Juglans, and Betula is observed. It is worth highlighting the presence of river taxa and Ericaceae (Unit 5).

The next units (3/4) are characterized by a decrease in Pinus, Corylus and Nitrophilus taxa offset by increase in Olea, Cupressaceae, and steppic non-tree taxa.
The sequence ends with an increase in Pinus, Corylus, Quercus (deciduous and evergreen), Juniperus, Ericaceae, and aquatic taxa, and a decrease in the steppic taxa (units $1 / 2$ ).

\section{DISCUSSION}

Despite the fragmentary nature of the stratigraphic records from Galeria de Estatuas (speleothem) and El Portalón (detrital) it has been possible to establish a palaeoenvironmental succession based on the integration of the different environmental parameters from both different proxies.

The comparison and integration of chronological dates obtained from ${ }^{14} \mathrm{C}$ (in the El Portalón site) and U/Th (Ilargi stalagmite) allows the definition of a common chronological framework. An important unconformity with an important hiatus has been recorded in both records, between the Upper Pleistocene to Holocene transition: $\sim 12$ to $\sim 8 \mathrm{kyr}$ $\mathrm{BP}$ in Margi and $\sim 20 \mathrm{ka}$, to $\sim 7 \mathrm{kyr} \mathrm{BP}$ in El Portalón. The presence of guano organic accumulation in both cases covering the surface of the unconformity makes it possible to use them as a broad-guide or correlation level, indicating the upper Pleistocene and the upper-middle Holocene boundary and the occurrence of significant environmental changes at that time.

The Upper Pleistocene ( 20 cal kyr BP) is represented by a steppe phase of Chenopodiaceae and Artemisia,

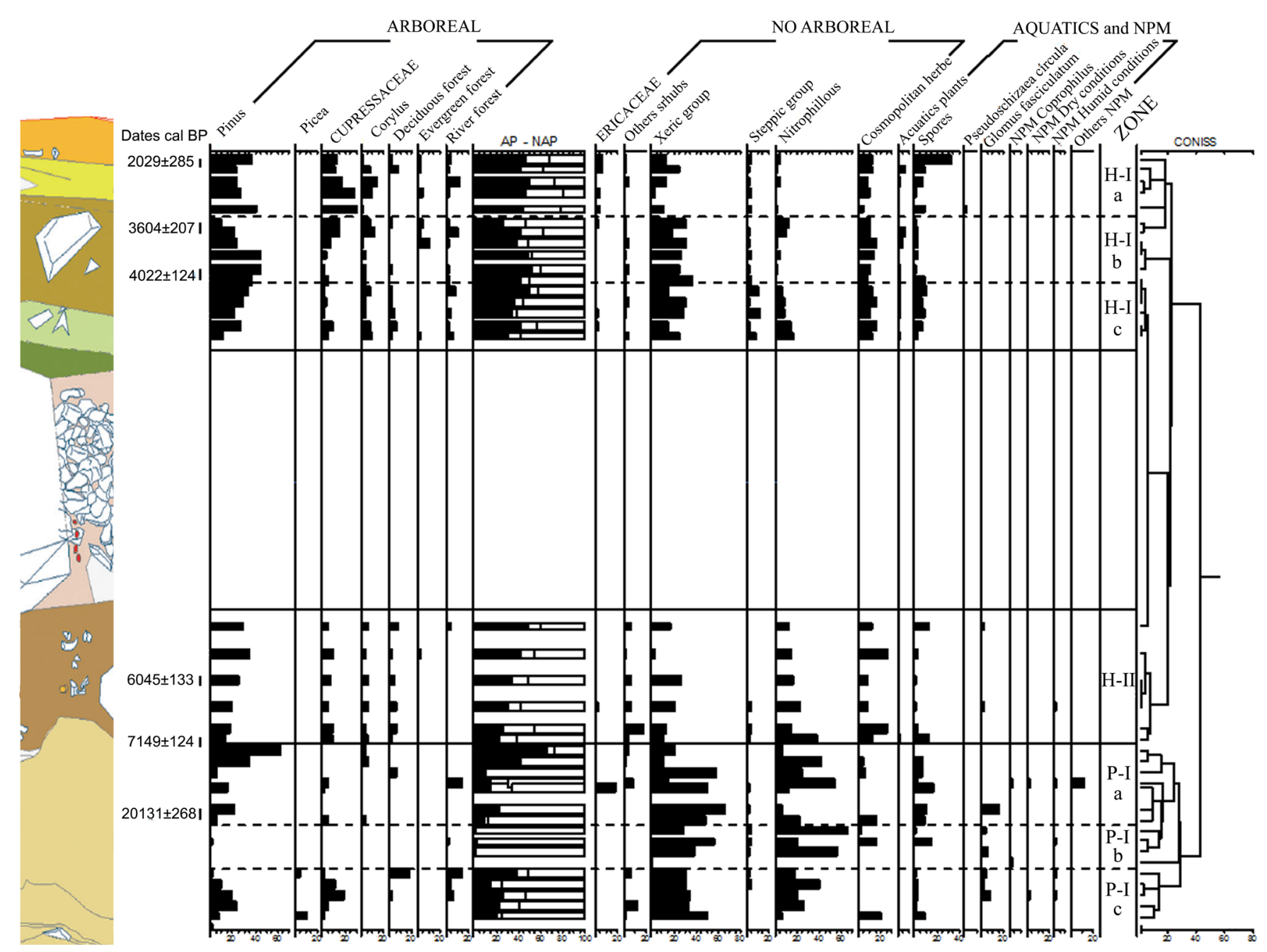

Fig. 6. Detailed palynological diagram of El Portalón site (south profile) with the most relevant taxa studied in percentages. 


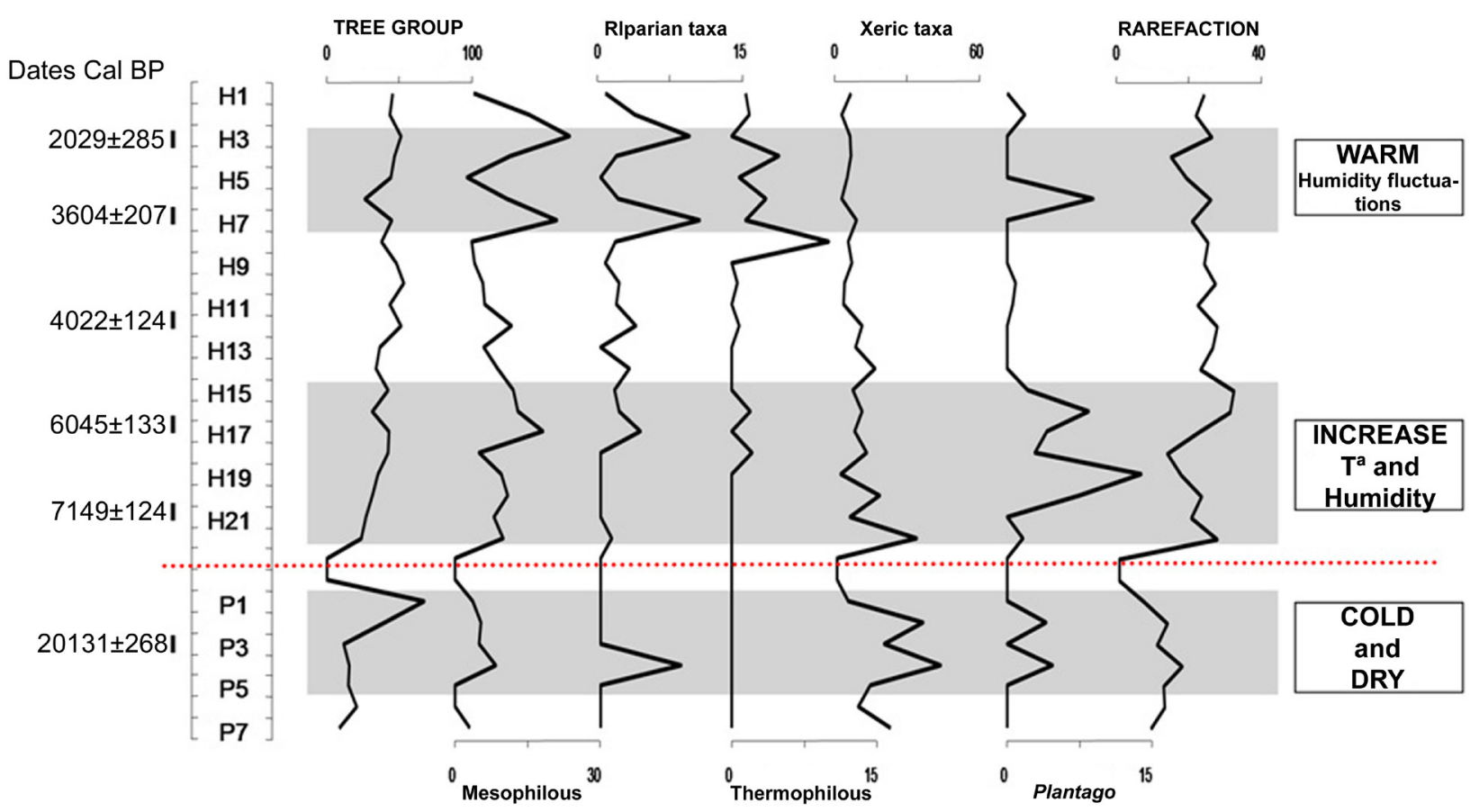

Fig. 7. Synthetic palynological diagram and rarefaction of the El Portalón site (south profile). The red dotted line marks the major sedimentary hiatus found at this site in the Pleistocene-Holocene transition.

indicating a cold and dry period (Figs. 6 and 7). In other neighbouring more complete pollen sequences, such as the one at Quintanar de la Sierra, Burgos (Peñalba et al., 1997), Sierra de Urbión, Soria (Ruiz Zapata et al., 2002, 2003a, 2003b, 2003c, Vegas et al., 2003) and Sierra de Cebollera, La Rioja (Gil García et al., 2001, 2002) (Fig. 8), the pollen record is characterised by fluctuating and increasingly extreme climate conditions (Fig. 9).

At this time, in the Galeria de Estatuas, formation of the speleothem had not yet begun. These conditions appear to evolve towards wetter and warmer ones which led to the initiation of the Ilargi speleothem. The columnar fabric of Unit I (Frisia et al., 2000; 2002 and Frisia \& Borsato, 2010) shows a constant dripping rate between $\sim 14$ and $\sim 13 \mathrm{kyr}$ BP (Fig. 3) and coincides with an increase in woodland (Pinus and Corylus), and a sharp decrease in the xeric group in the pollen record (Fig. 6 and 7). This increase in humidity and temperature is also recorded in speleothems from the Cantabrian margin (Moreno et al., 2010) and might even have reflected climate conditions similar to those of the present (Bølling-Allerød warming event, Severinghaus \& Brook, 1999).

The sedimentary record in the Cueva Mayor karst is abruptly interrupted by an erosion surface affecting both the archeological detritic record at El Portalón (Fig. 2) and the chemical record of the Galeria de Estatuas (Fig. 3). The erosional hiatus, fossilized by guano deposits in both cavities, extends from $12.8 \mathrm{kyr}$ to $7.7 \mathrm{cal} \mathrm{kyr} \mathrm{BP,}$ including the major climatic events of the beginning of the Holocene such as the Younger Dryas and the 8.2 Event. The erosive event affects both the detrital and the chemical sedimentation, and could be owing to a decrease in the sedimentation rate in El Portalón and erosion/dissolution by flooding or undersaturation of the drip water in the Ilargi stalagmite. The appearance of quartz and muscovite grains lining the erosive hiatus of the Ilargi stalagmite (Fig. 5c), could point to the occurrence of flooding event(s). This event would be correlated with the outset of a warm and wet period that started at $9 \mathrm{kyr}$ BP, the Holocene Climate Optimum that was punctuated by dry spells, such as the YD and 8.2 events. It is noteworthy that the early Holocene erosive hiatus in Ilargi coincides with optimum rates of stalagmite growth observed in the Cantabrian margin (Stoll et al., 2013).

From 7.7 cal kyr BP and until nearly 5 kyr BP, the high growth rate and the dendritic fabric of calcite crystals of the Ilargi stalagmite during Unit II indicates that the humidity from the climatic optimum continued

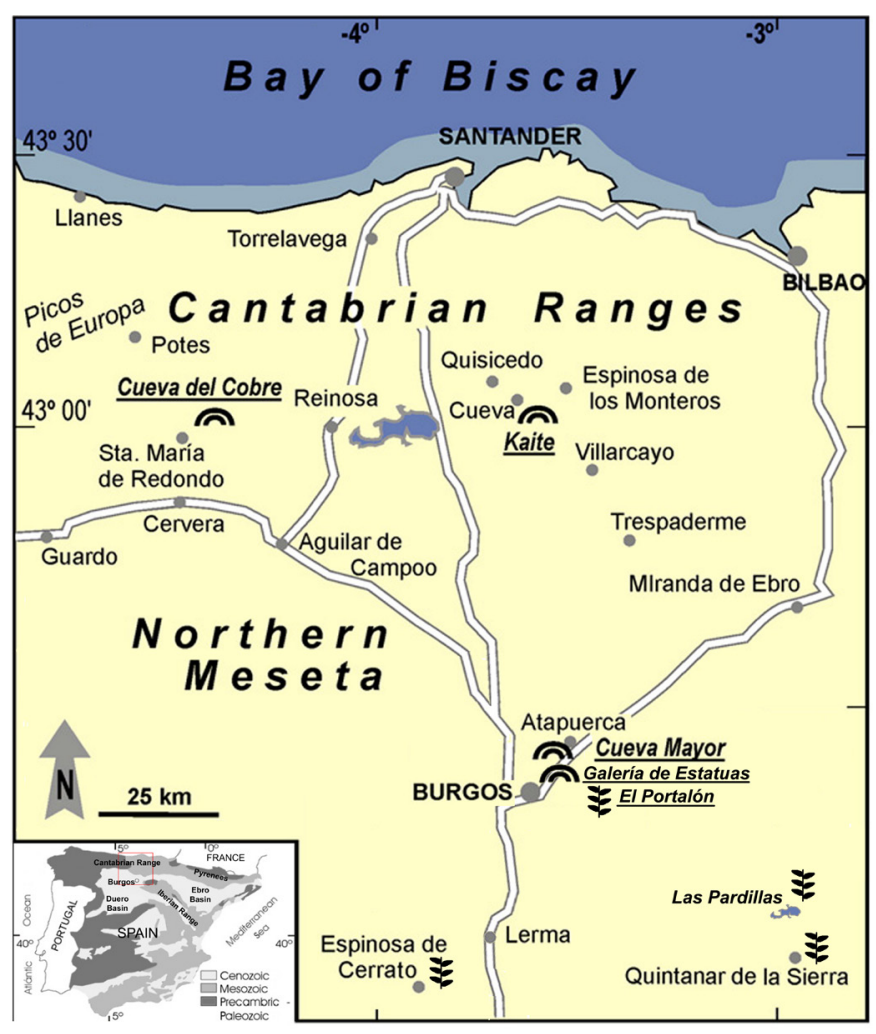

Fig. 8. Location of the neighbouring palynological and stalagmite sequences. Modified from Martín-Chivelet et al. (2011). 

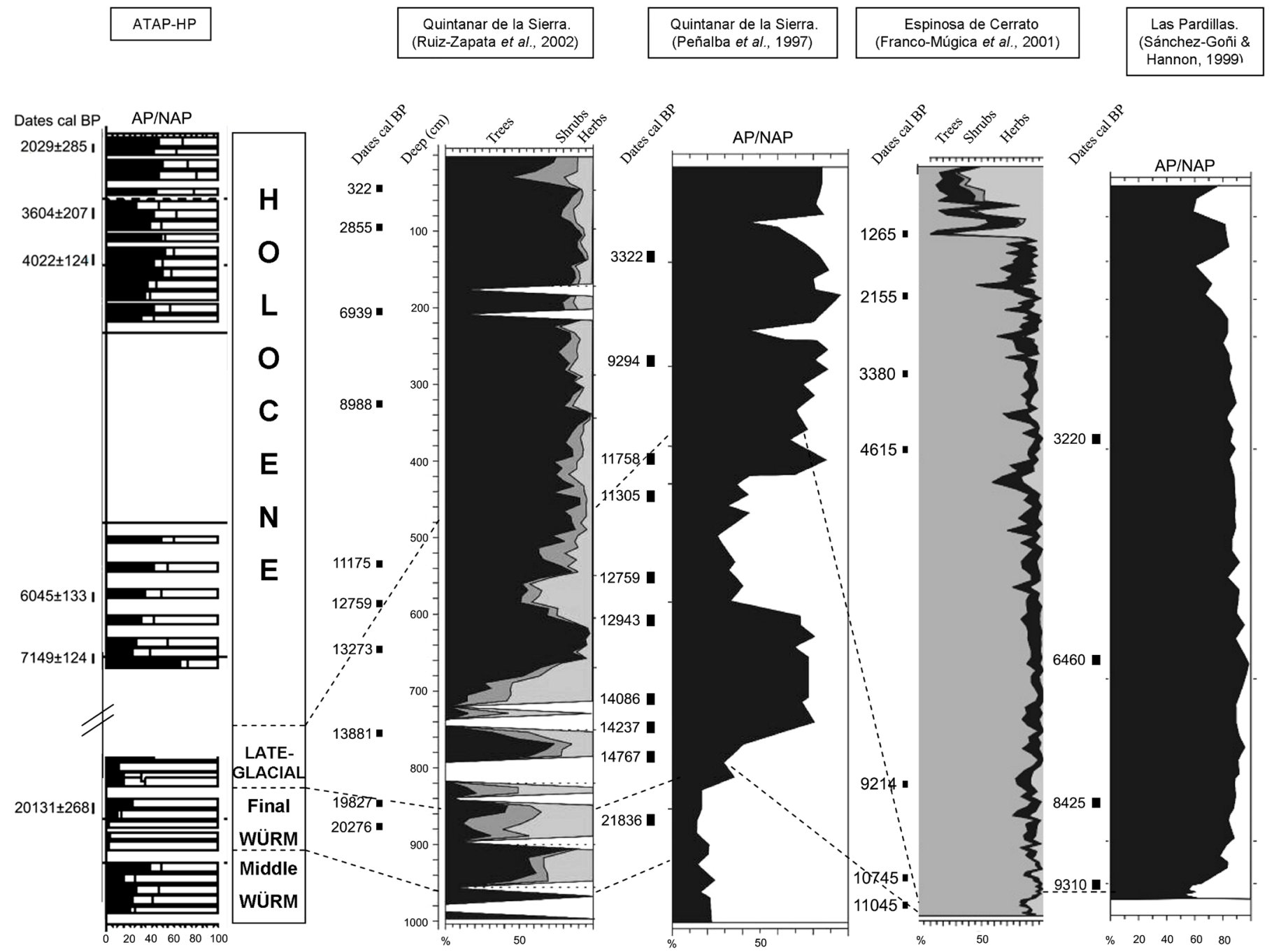

Fig. 9. Comparison between the palynological south profile of El Portalón site and the neighbouring sequences.

but with interspersed moments of either dripping non carbonate precipitation (prolonged periods of degasification and possible effect of evaporation) or extremely slow dripping and oversaturation (Frisia et al., 2000, 2002; Frisia \& Borsato, 2010). The presence of recrystallized crystalline fabrics (Fig. 5f) could be related to moments of stoppage of calcite precipitation. Accordingly, the pollen record from the El Portalón site shows typical vegetation of relatively wet conditions, with mesophilous and Mediterranean taxa, alternating with drier conditions with a slight increase in xeric taxa (Fig. 7). At these same chronologies, the first Neolithic occupations have been identified in Unit 9 of the El Portalón site (Fig. 6) (Carretero et al., 2008) with cereal remains corresponding to the beginnings of the agriculture in the area that probably benefited from a more seasonal Mediterranean climate.

The environmental conditions became gradually drier from $5 \mathrm{kyr}$ BP onwards with a decline in the growth rate of the Ilargi speleothem during Unit III. A marked cyclicity is defined in the Unit III by the alternation of microcrystalline and micritic laminae, indicating drier periods (Frisia et al., 2000, 2002; Frisia $\&$ Borsato, 2010). Eventually ash-rich laminae with soot sedimented in the intercrystalline porosity appear (Fig. 5h). These black soot laminae are interpreted as being derived from man-made fires nearby. At this time, there is evidence of intensive Iron Age occupation and abundant anthropic fires in the El Portalón site (e.g. fumiers) and presence of human activity in the Galeria de Estatuas with excavation of storage pits (Ortega Martínez, 2009). The cyclicity corresponding to a possible marked seasonality is inferred from the repetition of the wet/dry sequences, which may be annual or of longer duration; this issue is not possible to establish more precisely with the available data.

The increase in dryness detected coincides with a rapid climate change event, intense warming and drying, in the middle Holocene (i.e. Yu et al., 1997). The archeostratigraphical and pollen record of the El Portalón site, however, enables a more detailed study of this aridification phase. During the 5.2-3.3 cal kyr $\mathrm{BP}$ interval, a certain stabilisation of the woodlands can be observed with a complete cycle of flourishment and decline of Pinus, offset by Cupressaceae, Corylus and Quercus, and a very widespread non-tree xeric group. Moreover, constant presence of riparian and aquatic taxa has been recorded, evidencing the presence of the Arlanzon river course in the vicinity of the Sierra de Atapuerca. Towards the upper part of Unit 3 of the El Portalón site ( 4 cal kyr BP) there is a major decline in the woodlands (at the expense of Pinus as against Cupressaceae and Corylus), and a slight increase both in nitrophilous and xeric taxa 
(Fig. 6 and 7). In the case of Atapuerca, this reduction in the woodlands could possibly have been amplified by anthrophication and consequent changes to the regional landscape (deforestation and agriculture), evidenced by a more intense human occupation of the cave during the Bronze Age and the greater number of ash-rich laminae in the Ilargi stalagmite. This progressive environmental change to warmer and drier conditions rapidly accelerates with a marked decrease in the growth rate of the speleothem and a thinner sedimentological record in the El Portalón site (less than $1 \mathrm{~m}$ thick in the last $3.3 \mathrm{cal} \mathrm{kyr} \mathrm{BP}$, as compared to the $5 \mathrm{~m}$ accumulated between 6.3 and $3.3 \mathrm{cal} \mathrm{kyr} \mathrm{BP).}$

Up to now, the only speleothem studies in the north Iberian plateau begin in this age range (DominguezVillar et al., 2008; Martín-Chivelet et al., 2011), so a comparison between Ilargi and other speleothem records is not possible beyond 4000 yr (Fig.10).

A stratigraphic-cultural hiatus affecting the Late Bronze Age in the El Portalón site marks the onset of Iron I age Unit 2 (Carretero et al., 2008) characterised by a local tree landscape made up primarily of Cupressaceae, and a relative decline in xeric taxa (Fig. 6 and 7). Finally, the archeostratigraphic record of the El Portalón site ends with sporadic occupations in early imperial and medieval moments from Units 2 and 1 (Carretero et al., 2008) (Fig. 2) that show an increase of Pinus, Corylus, Quercus (deciduous and evergreen), Juniperus, Ericaceae and aquatic taxa.
The integration of the studied speleothem and archeostratigrapic-palinological records of the Cueva Mayor karst, makes it possible to identify and characterize different climatic periods and to develop a continuous temporal sequence during the Holocene and Upper Pleistocene in the Sierra de Atapuerca (Fig. 11).

\section{CONCLUSIONS}

With regard to the palaeoenvironmental data obtained from the Ilargi speleothem, the data obtained from El Portalón excavations are of great importance because of the scarcity of information regarding the Upper Palaeolithic, Mesolithic and Neolithic cultural periods in the interior of the Iberian Peninsula. The time interval recorded in the Ilargi speleothem $(\sim 14$ kyr BP - present) and in the pollen sequence of the archaeological sediments of the El Portalón site $(\sim 20$ - 2 cal kyr BP) overlap at $\sim 14-2$ kyr BP allowing comparison of the differenttypes of palaeoenvironmental records to confirm the robustness of interpretations. Integrating the pollen data and the petrographic study of stalagmites shows that the latter may not only provide palaeoenvironmental information on the context in which they were formed, but may also record evidence of human activity throughout cave systems. Correlation and integration of the archeostratigraphic and speleothem records establishes well-differentiated palaeoclimatic intervals for the Sierra de Atapuerca and surrounding areas.

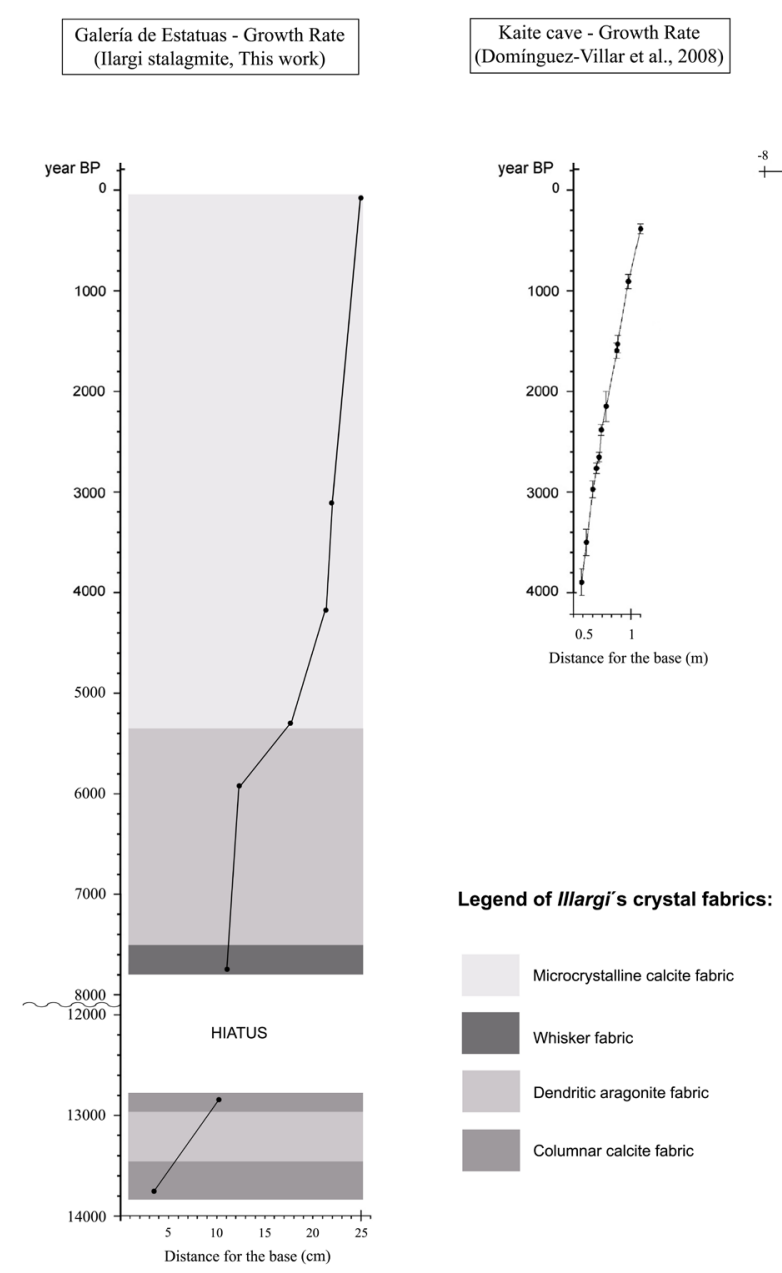

Fig. 10. Comparison between the different fabrics and growth-rate of the Ilargi stalagmite and the most neighbouring stalagmites. Note the distances from the bases are not to the same scale. 


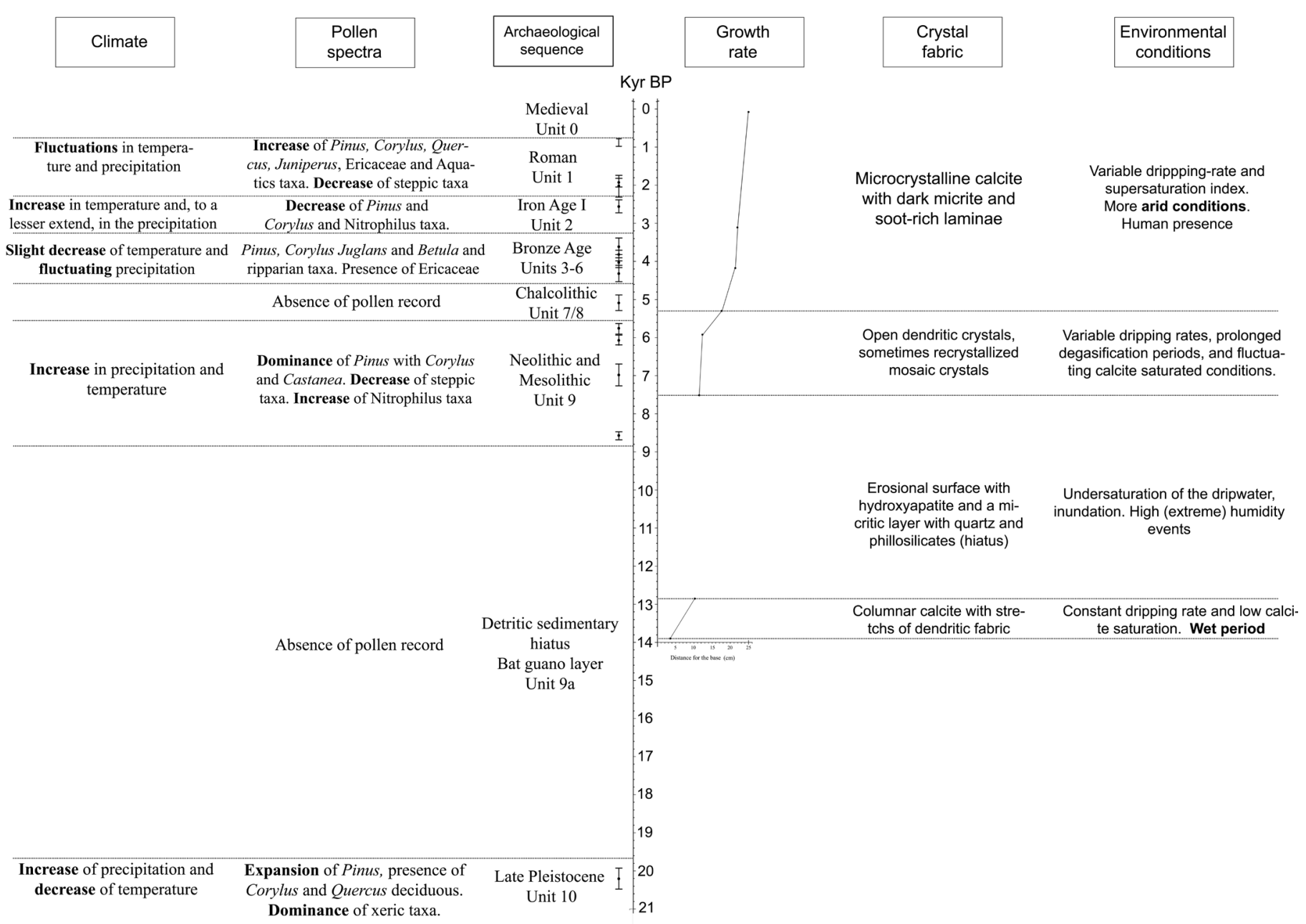

Fig. 11. Synthesis diagram of the two records studied and compared in this work from the Cueva Mayor karst system of Atapuerca.

From the Upper Pleistocene ( 20 cal kyr BP) we identify a cold dry episode that appears to evolve towards wetter and warmer conditions around $13.7 \mathrm{kyr} \mathrm{BP}$ that led to the initiation of the Margi stalagmite. This increase in humidity and temperature lasted until $12.8 \mathrm{kyr} \mathrm{BP}$ and might have reflected climate conditions similar to those of the BøllingAllerød warm interval.

A major hiatus of at least $5 \mathrm{kyr}$ represents the uppermost Pleistocene and the onset of the Holocene $(12.8 \mathrm{kyr}-7.7 \mathrm{cal}$ kyr BP). This erosive episode, and the subsequent guano deposits, includes both the Younger Dryas and the 8.2 Event.

From $7.7 \mathrm{cal}$ kyr BP onwards, the existence of alternating environmental conditions and human occupation in Cueva Mayor are detected, both at the entrance (El Portalón site) and in the interior of the karstic system (Galeria de Estatuas).

The environmental conditions became significantly drier around $4 \mathrm{cal} \mathrm{kyr} \mathrm{BP} \mathrm{causing} \mathrm{a} \mathrm{reduction} \mathrm{of} \mathrm{woodland}$ and nitrophilous taxa and an increase in xeric taxa. This circumstance could be amplified by the increasing and more intense human occupation and agricultural activity during the Bronze Age that was also recorded in the soot-rich laminae derived from man-made fires in the studied stalagmite.

\section{ACKNOWLEDGEMENTS}

This research was carried out as part of the Spanish Ministry of Science and Innovation's research project
CGL2009-12703-C03-03 (sub-programme BTE), the ERC Project No: 230561-AGRIWESTMED, EHU 11/21 and within the "Geología del Karst" research activities by the EHU/Aranzadi Geo-Q Research Center. The first author is supported by a research grant, the "Ayuda Fundación Repsol" from the Fundación Atapuerca. The authors would like to acknowledge the support of the excavation and research groups of the Galería de Estatuas and El Portalón sites, the Centro Mixto UCM-ISCIII de Evolución y Comportamiento Humanos, the geochronology laboratories of the University of Minneapolis (Minnesota, United States) and the SGIker research facilities of the Universidad del País Vasco (UPV/EHU) for their collaboration, and to Ana Mendez-Vicente and Saúl González-Lemos for their help with the preparation of samples for U/Th dating. Special thanks to Tim Nicholson for translation of this manuscript, and to the referees for their corrections and improvements.

\section{REFERENCES}

Arsuaga J.L., Martinez I., Gracia A., Carretero J.M., Lorenzo C., García N. \& Ortega A.I., 1997 - Sima de los Huesos (Sierra de Atapuerca). The site. Journal of Human Evolution, 33: 109-127. http://dx.doi.org/10.1006/jhev.1997.0132 
Bermúdez de Castro J.M., Arsuaga J.L., Carbonell E., Rosas A., Martínez I. \& Mosquera M., 1997 - A hominid from Lower Pleistocene of Atapuerca, Spain: possible ancestor to Neanderthals and modern humans. Science, 276: 1392-1395. http://dx.doi.org/10.1126/science.276.5317.1392

Birks H.J.B. \& Line J.M., 1992 - The use of rarefaction analysis for estimating palynological richness from Quaternary pollen-analytical data. The Holocene, 2 (1): 1-10.

Bronk Ramsey C., Highman T.F.G., Owen D.C., Pike A.W.G. \& Hedges R.E.M., 2002 - Radiocarbon dates from the Oxford AMS system: archaeometry datelist 31. Archaeometry, 44 (suppl.1): 65-67.

Carbonell E., Bermúdez de Castro J.M., Arsuaga J.L., Diez J.C., Rosas A., Cuenca Bescós G., Sala R., Mosquera M. \& Rodríguez X.P., 1995 - Lower Pleistocene hominids and artefacts from AtapuercaTD6 (Spain). Science, 269: 826-832.

http://dx.doi.org/10.1126/science.7638598

Carbonell E., Bermúdez De Castro J.M., Parés J.M., Pérez-González A., Cuenca-Bescós G., Ollé A., Mosquera M., Huguet R., Van Der Made J., Rosas A., Sala R., Vallverdú J., García N., Granger D.E., Martinón-Torres M., Rodríguez X.P., Stock G.M., Vergés J.M., Allué E., Burjachs F., Cáceres I., Canals A., Benito A., Díez C., Lozano M., Mateos A., Navazo M., Rodríguez J., Rosell J. \& Arsuaga J.L., 2008 - The first hominin of Europe. Nature, 452: 365-370.

http://dx.doi.org/10.1038/nature06815

Carretero J.M., Ortega A.I., Juez L., Pérez-González A., Arsuaga J.L., Pérez-Martínez R. \& Ortega M.C., 2008 - A Late Pleistocene-Early Holocene archaeological sequence of Portalón de Cueva Mayor (Sierra de Atapuerca, Burgos, Spain). Munibe (Antropologia-Arkeologia), 59: 67-80.

Cheng H., Fleitmann D., Edwards R.L., Wang X.F., Cruz F.W., Auler A.S., Mangini A., Wang Y.J., Kong X.G., Burns S.J. \& Matter A., 2009 - Timing and structure of the $8.2 \mathrm{kyr} B P$ event inferred from $\delta^{18} \mathrm{O}$ records of stalagmites from China, Oman, and Brazil. Geology, 37: 1007-1010.

http://dx.doi.org/10.1130/G30126A.1

Clark G., Straus L.G., Burton S.S. \& Jackson-Clark V., 1979 - The North Burgos Archaeological Survey: An inventory of cultural remains. In Clark G. (Ed.), Bronze and Iron Age archaeology on the Meseta del Norte (Province of Burgos, North-Central Spain). Anthropological Research papers, 19: 18-156. Arizona: Arizona State University.

Coûteaux M., 1977 - A propos de l'interpretation des analyses polliniques de sediments minéraux, principalement archéologiques. In: Le Milieu Végétal, les faunas et l'Homme. Supplément Bulletin A.F.E.Q., 47: 259-276.

Domínguez-Villar D., Wang X., Cheng H., Martín-Chivelet J. \& Edwards R.L., 2008 - A high-resolution late Holocene speleothem record from Kaite Cave, northern Spain: $\delta^{18} O$ variability and possible causes. Quaternary International, 187: 40-51.

http://dx.doi.org/10.1016/j.quaint.2007.06.010

Dorale J.A., Edwards R.L., Alexander E.C., Shen C.C., Richards D.A. \& Cheng H., 2004 - Uranium-series dating of speleothems: current techniques, limits and applications. In: Mylroie J.E. \& Sasowsky I.D. (Eds), Studies of Cave Sediments: Physical and Chemical Records of Paleoclimate. Kluwer Academy/Plenum Publishers, New York, 177-197.

Edwards R.L., Chen J.H. \& Wasserburg G.J., 1987 ${ }^{238} \mathrm{U}^{234} \mathrm{U}^{230} \mathrm{Th}-{ }^{232} \mathrm{Th}$ systematics and the precise measurements of time over the past 500000 years. Earth and Planetary Science Letters, 81: 175-192.
Falguères C., Bahain J.J., Yokoyama Y., Bischoff J.L., Arsuaga J.L., Bermúdez De Castro J.M., Carbonell E. \& Dolo J.M., 2001 - Datation par RPE et U-Th des sites pleistocènes d'Atapuerca: Sima de los Huesos, Trinchera Dolina et Galería. Bilan géochronologique. L'Anthropologie, 105: 71-81.

http://dx.doi.org/10.1016/S0003-5521(01)80006-6

Foote M., 1992 - Rarefaction analysis of morphological and taxonomic diversity. Paleobiology, 18 (1): 1-16.

Frisia S. \& Borsato A., 2010 - Karst. In: Alonso Zarza A.M. \& Tanner L.H., 2010 - Carbonates in continental settings: Facies, environments and processes. Developments in Sedimentology, 6: $393 \mathrm{p}$.

Frisia S., Borsato A., Fairchild I.J. \& McDermott F., 2000 - Calcite fabrics, growth mechanisms, and environments of formation in speleothems from the Italian Alps and southwestern Ireland. Journal of Sedimentary Research, 70: 1183-1196. http://dx.doi.org/10.1306/022900701183

Frisia S., Borsato A., Fairchild I.J., McDermott F. \& Selmo E.M., 2002 - Aragonite calcite relationships in speleothems (Grotte de Clamouse, France): environment, fabrics, and carbonate geochemistry. Journal of Sedimentary Research, 72: 687-699. http://dx.doi.org/10.1306/020702720687

Gil García M.J., Ruiz Zapata B., Dorado Valiño M., Valdeolmillos A. \& Pérez-González A., 2001 Caracterización climática de la transición Pleistoceno superior-Holoceno en el Sistema Ibérico. In: Meléndez G., Herrera Z., Delvene G. \& Azanza B. (Eds.), Los fósiles y la Paleogeografia. Publicaciones del Seminario de Paleontología (SEPAZ), Zaragoza: 100-106.

Gil García M.J., Dorado Valiño M., Valdeolmillos Rodriguez A. \& Ruiz Zapata M.B., 2002 - Late-glacial and Holocene paleoclimatic record from Sierra de Cebollera (northern Iberian range, Spain). Quaternary International, 93-94: 13-18.

http://dx.doi.org/10.1016/S1040-6182(02)00003-4

Girard M. \& Renault-Miskovsky J., 1969 - Nouvelles techniques de préparation en palynologie appliquées à trois sédiments du Quaternaire final de l'Abri Cornille (Istres, Bouches du Rhône). Bulletin de l'Association française pour 1`Etude du Quaternaire, 4: 275-284.

Goeury C.L. \& Beaulieu J.L., 1979 - À propos de la concentration du pollen à l'aide de la liquer de Thoulet dans les sediments minéraux. Pollen et Spores, 21: 239-251.

Grimm E.C., 1987 - Coniss: a FORTRAN 77 program for stratigraphically constrained cluster analysis by the method of incremental sum of squares. Computers \& Geosciences, 13: 13-35.

Heck K.L., Van Belle G. \& Simberloff D., 1975 - Explicit calculation of the rarefaction diversity measurement and the determination of sufficient simple size. Ecology, 56: 1459-1461. http://dx.doi.org/10.2307/1934716

Kendall A.C. \& Broughton P.L., 1978 - Origin of fabrics in speleothems composed of columnar calcite crystals. Journal of Sedimentary Petrology, 48: 519-538.

López-García J.M., Blain H.A., Cuenca-Bescós G., RuizZapata M.B., Dorado-Valiño M., Gil García M.J., Valdeolmillos A., Ortega A.I., Carretero J.M., Arsuaga J.L., Bermúdez de Castro J.M. \& Carbonell E., 2010 Palaeoenvironmental and palaeoclimatic reconstruction of the Latest Pleistocene of El Portalón Site, Sierra de Atapuerca, northwestern Spain. Palaeogeography, Palaeoclimatology, Palaeoecology, 292 (3-4): 453-464. http://dx.doi.org/10.1016/j.palaeo.2010.04.006

López-Sáez J.A., López García P.B \& Burjachs F., 2003 Arqueopalinologia: sintesis crítica. Polen, 12: 5-35.

Martinez I., Rosa M., Arsuaga J.L., Jarabe P., Quam R., Lorenzo C., Gracia A., Carretero J.M., Bermúdez de Castro J.M. \& Carbonell E., 2004 - Auditory capacities in Middle Pleistocene humans from the Sierra de Atapuerca in Spain. Proceedings of the National Academy of Sciences of USA, 101: 9976-9981. http://dx.doi.org/10.1073/pnas.0403595101 
Martín-Chivelet J., Muñoz-García M.B., Edwards R.L., Turrero M.J. \& Ortega A.I., 2011 - Land surface temperature changes in Northern Iberia since 4000 yr BP, based on $\delta^{13} \mathrm{C}$ of speleothems. Global and Planetary Change, 77: 1-12. http://dx.doi.org/10.1016/j.gloplacha.2011.02.002

Moore P.D., Webb J.A. \& Collinson M.E., 1991 - Pollen analysis (Second edition). Oxford. Blackwell, 216 p.

Moreno A., Stoll H., Jiménez-Sánchez M., Cacho I., Valero-Garcés B., Ito E. \& Edwards R.L., 2010 - A speleothem record of glacial (25-11.6 kyr BP) rapid climatic changes from northern Iberian Peninsula. Global and Planetary Change, 71 (3-4): 218-231. http://dx.doi.org/10.1016/j.gloplacha.2009.10.002

Moreno D., Falguères C., Pérez-González A., Duval M., Voinchet P., Benito-Calvo A., Ortega A.I., Bahain J.J., Sala R., Carbonell E., Bermúdez de Castro J.M. \& Arsuaga J.L., 2012 - ESR chronology of alluvial deposits in the Arlanzón valley (Atapuerca, Spain): contemporaneity with Atapuerca Gran Dolina site. Quaternary Geochronology, 10: 418-423.

http://dx.doi.org/10.1016/j.quageo.2012.04.018

Muñoz A., Peña J.L., Sancho C. \& Martínez A.M., 2001 - Espeleotemas de la Cueva de Ortigosa. dataciones y paleoambiente. Geogaceta, 30: 95-98.

Muñoz García M.B., 2007 - Los espeleotemas holocenos y pleistocenos de la Cueva del Cobre (Sierra de Peña Labra, Palencia) como indicadores de Variabilidad Climática. Thesis, $322 \mathrm{p}$.

Odgaard B.V., 1999 - Fossil pollen as a record of past biodiversity. Journal of Biogeography, 26 (1): 7-17. http://dx.doi.org/10.1046/j.1365-2699.1999.00280.x

Ortega Martínez A.I., 2009 - La evolución geomorfológica del karst de la Sierra de Atapuerca (Burgos) y su relación con los yacimientos pleistocenos. $\mathrm{PhD}$ Thesis, Universidad de Burgos, $624 \mathrm{p}$.

Peñalba M.C., Arnold M., Guiot J., Duplessy J.C. \& De Beaulieu J.L., 1997 - Termination of the last glaciation in the Iberian Peninsula inferred from the pollen sequence of Quintanar de la Sierra. Quaternary Research, 48: 205-214. http://dx.doi.org/10.1006/qres.1997.1922

Railsback, L.B., Liang, F., Vidal Romaní, J.R., Grandald'Anglade, A., Vaqueiro Rodríguez, M., Santos Fidalgo, L., Fernández Mosquera, D., Cheng, H. \& Edwards R.L., 2011 - Petrographic and isotopic evidence for Holocene long-term climate change and shorter-term environmental shifts from a stalagmite from the Serra do Courel of northwestern Spain, and implications for climatic history across Europe and the Mediterranean. Palaeogeography, Palaeoclimatology, Palaeoecology, 305: 172-184. http://dx.doi.org/10.1016/j.palaeo.2011.02.030

Ruiz Zapata M.B., Gil García, M.J., Dorado Valiño M., Valdeolmillos A., Vegas J. \& Pérez-González A., 2002 Clima y vegetación durante el Tardiglaciar y el Holoceno en la Sierra de Neila (Sistema Ibérico Noroccidental). Cuaternario y Geomorfología, 16 (1-4): 9-20.
Ruiz Zapata M.B., Ortega A., Dorado Valiño M., Valdeolmillos A., Gil García M.J., Carretero J.M., Martínez-Mendizabal I. \& Arsuaga J.L., 2003a - Vegetational history during Bronze and Iron Ages in Portalón Cave (Sierra de Atapuerca, Burgos, Spain). In: Ruiz Zapata M.B., Dorado M., Valdeolmillos A., Gil García M.J., Bardají T., Bustamante I. \& Martinez I. (Eds.), Quaternary climatic changes and environmental crises in the Mediterranean Region. Servicio de Publicaciones de la Universidad de Alcalá. Madrid: 99-106.

Ruiz Zapata M.B., Gil García M.J., Vegas J., Dorado Valiño M., Valdeolmillos A. \& Pérez-González A., 2003b - Registro palinológico de los eventos Heinrich (H1 y H2) en la secuencia de La Laguna Grande (Sierra de Neila. Sistema Ibérico. España). In: XI Reunión Nacional de Cuaternario. Flor. G. (Ed.), Servitec. Oviedo: 293- 300.

Ruiz Zapata M.B., Gil García M.J., Dorado Valiño M., Valdeolmillos A., Vegas J. \& Pérez-González A., 2003c - Caracterización palinológica de los últimos grandes eventos fríos del Máximo Glaciar en secuencias de la Peninsula Ibérica. In: Collantes M.M., Sayago J.M. \& Neder L.V. (Eds.), Actas II Congreso Argentino de Cuaternario y Geomorfología: 165-176.

Scholz D. \& Hoffman D.L., 2011 - StalAge - An algorithm designed for construction of speleothem age models. Quaternary Geochronology, 6: 369-382. http://dx.doi.org/10.1016/j.quageo.2011.02.002

Severinghaus J.P. \& Brook E.J., 1999 - Abrupt climate change at the end of the last glacial period inferred from trapped air in polar ice. Science, 286: 930-934. http://dx.doi.org/10.1126/science.286.5441.930

Shen C.C., Edwards R.L., Cheng H., Dorale J.A., Thomas R.B., Moran S.B., Weinstein S.E. \& Edmonds H.N., 2002 - Uranium and thorium isotopic and concentration measurements by magnetic sector inductively coupled plasma mass spectrometry. Chemical Geology, 185: 165-178. http://dx.doi.org/10.1016/S0009-2541(01)00404-1

Stoll H.M., Moreno A., Mendez-Vicente A., GonzalezLemos S., Jimenez-Sanchez M., Dominguez-Cuesta M.J., Edwards R.L., Cheng H. \& Wang X., 2013Paleoclimate and growth rates of speleothems in the northwestern Iberian Peninsula over the last two glacial cycles. Quaternary Research, 80 (2): 284-290. http://dx.doi.org/10.1016/j.yqres.2013.05.002

Vegas J., Pérez-González A., Ruiz Zapata M.B., Gil García M.J., Dorado Valiño M., Valdeolmillos A. \& López M.J., 2003 - The GS-1/Younges Dryas event in the Laguna Grande Lacustrine record. Late Glaciar-Holocene transition in the NW Iberian Range, Spain. In: Valero B.L. (Ed.), Limnogeology in Spain: atribute to Kerry R. Kelt. Consejo Superior de Investigaciones Científicas: 283-304.

Yu E., McAndrews J.H. \& Eicher U., 1997 - Middle Holocene dry climate caused by change in atmospheric circulation patterns: Evidence from lake levels and stable isotopes. Geology, 25 (3): 251-254. http://dx.doi.org/10.1130/00917613(1997)025<0251:MHDCCB>2.3.CO;2 